\title{
Codes for the Identification of Federal and Federally-Assisted Organizations
}

Hildegard Ferraiolo

This publication is available free of charge from:

https://doi.org/10.6028/NIST.SP.800-87r2

\section{OMPUTER SECUR I T Y}




\title{
NIST Special Publication 800-87 Revision 2
}

\section{Codes for the Identification of Federal and Federally-Assisted Organizations}

\author{
Hildegard Ferraiolo \\ Computer Security Division \\ Information Technology Laboratory
}

This publication is available free of charge from:

https://doi.org/10.6028/NIST.SP.800-87r2

April 2018

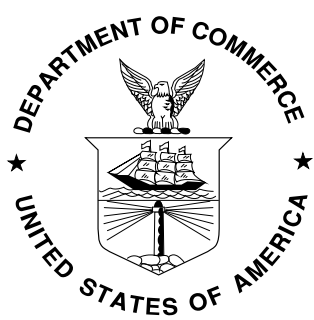

U.S. Department of Commerce

Wilbur L. Ross, Jr., Secretary

National Institute of Standards and Technology Walter Copan, NIST Director and Under Secretary of Commerce for Standards and Technology 


\title{
Authority
}

This publication has been developed by NIST in accordance with its statutory responsibilities under the Federal Information Security Modernization Act (FISMA) of 2014, 44 U.S.C. § 3551 et seq., Public Law (P.L.) 113-283. NIST is responsible for developing information security standards and guidelines, including minimum requirements for federal information systems, but such standards and guidelines shall not apply to national security systems without the express approval of appropriate federal officials exercising policy authority over such systems. This guideline is consistent with the requirements of the Office of Management and Budget (OMB) Circular A-130.

Nothing in this publication should be taken to contradict the standards and guidelines made mandatory and binding on federal agencies by the Secretary of Commerce under statutory authority. Nor should these guidelines be interpreted as altering or superseding the existing authorities of the Secretary of Commerce, Director of the OMB, or any other federal official. This publication may be used by nongovernmental organizations on a voluntary basis and is not subject to copyright in the United States. Attribution would, however, be appreciated by NIST.

\section{National Institute of Standards and Technology Special Publication 800-87 Revision 2 Natl. Inst. Stand. Technol. Spec. Publ. 800-87 Revision 2, 105 pages (April 2018) CODEN: NSPUE2}

This publication is available free of charge from: https://doi.org/10.6028/NIST.SP.800-87r2

Certain commercial entities, equipment, or materials may be identified in this document in order to describe an experimental procedure or concept adequately. Such identification is not intended to imply recommendation or endorsement by NIST, nor is it intended to imply that the entities, materials, or equipment are necessarily the best available for the purpose.

There may be references in this publication to other publications currently under development by NIST in accordance with its assigned statutory responsibilities. The information in this publication, including concepts and methodologies, may be used by federal agencies even before the completion of such companion publications. Thus, until each publication is completed, current requirements, guidelines, and procedures, where they exist, remain operative. For planning and transition purposes, Federal agencies may wish to closely follow the development of these new publications by NIST.

Organizations are encouraged to review all draft publications during public comment periods and provide feedback to NIST. Many NIST cybersecurity publications, other than the ones noted above, are available at https://csrc.nist.gov/publications.

\section{Comments on this publication may be submitted to:}

\author{
National Institute of Standards and Technology \\ Attn: Computer Security Division, Information Technology Laboratory \\ 100 Bureau Drive (Mail Stop 8930) Gaithersburg, MD 20899-8930 \\ Email: piv comments@nist.gov
}

All comments are subject to release under the Freedom of Information Act (FOIA). 


\title{
Reports on Computer Systems Technology
}

The Information Technology Laboratory (ITL) at the National Institute of Standards and Technology (NIST) promotes the U.S. economy and public welfare by providing technical leadership for the Nation's measurement and standards infrastructure. ITL develops tests, test methods, reference data, proof of concept implementations, and technical analyses to advance the development and productive use of information technology. ITL's responsibilities include the development of management, administrative, technical, and physical standards and guidelines for the cost-effective security and privacy of other than national security-related information in federal information systems. The Special Publication 800-series reports on ITL's research, guidelines, and outreach efforts in information system security, and its collaborative activities with industry, government, and academic organizations.

\begin{abstract}
This document provides the organizational codes for federal agencies to establish the Federal Agency Smart Credential Number (FASC-N) that is required to be included in the FIPS 201 Card Holder Unique Identifier. SP 800-87 is a companion document to FIPS 201.
\end{abstract}

\section{Keywords}

CHUID; Federal Agency Smart Credential Number (FASC-N); FIPS 201; HSPD-12; organizational codes; identity credential; PIV cards. 
Executive Summary

The Homeland Security Presidential Directive HSPD-12 called for new standards to be adopted governing the interoperable use of identity credentials to allow physical and logical access to Federal government locations and systems. Personal Identity Verification (PIV) for Federal Employees and Contractors, (Federal Information Processing Standard 201 (FIPS 201)) was developed to establish standards for identity credentials. This document, Special Publication (SP) 800-87, provides the organizational codes necessary to establish the PIV Federal Agency Smart Credential Number (PIV FASC-N) that is required to be included in the FIPS 201 Card Holder Unique Identifier (CHUID) and is a companion document to FIPS 201. 


\section{Table of Contents}

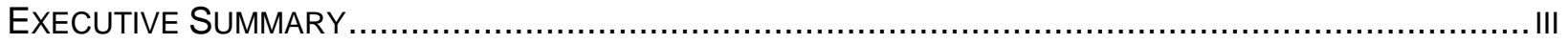

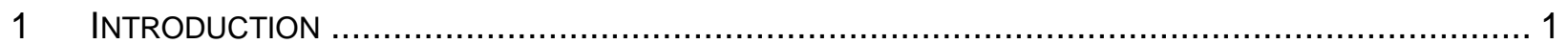

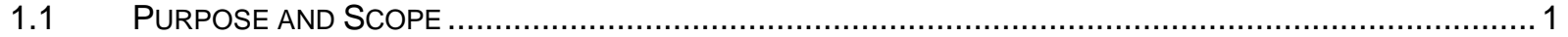

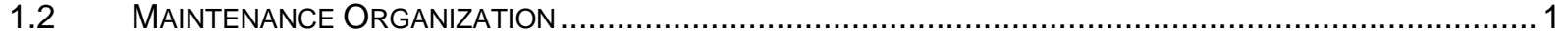

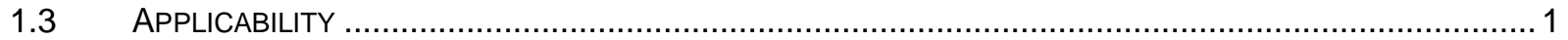

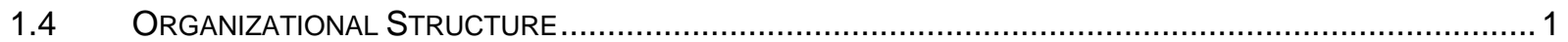

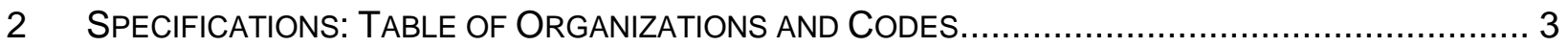

2.1 PART A: ARRANGEMENT BY HIERARCHICAL AND BUDGETARY RELATIONSHIP ...............................

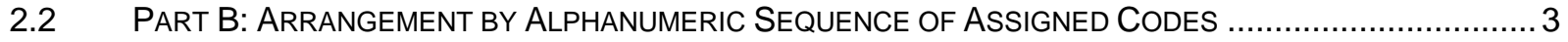

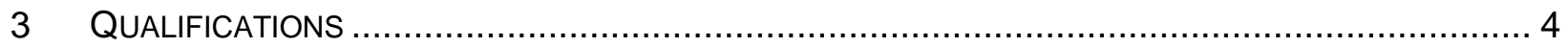

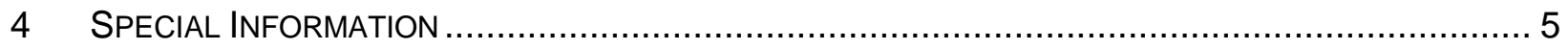

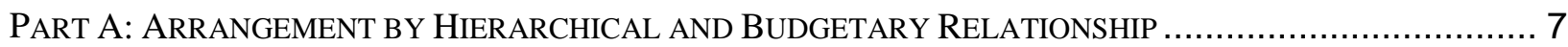

PART B: ARRANGEMENT BY ALPHANUMERIC SEQUENCE OF ASSIGNED CODES ...........................67

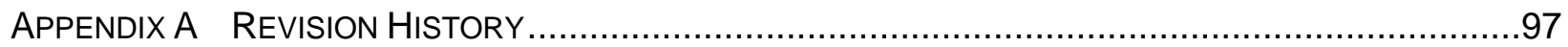




\section{Introduction}

\subsection{Purpose and Scope}

Federal Information Processing Standard (FIPS) $201^{1}$ was developed to establish standards for identity credentials for federal employees and federal contractors. This document provides the organizational codes for federal agencies to establish the Federal Agency Smart Credential Number (FASC-N) that is required to be included in the FIPS 201 Card Holder Unique Identifier. Special Publication (SP) 800-87 is a companion document to FIPS 201. All changes implemented in this publication are listed in Appendix A.

\subsection{Maintenance Organization}

The maintenance organization for codes for the identification of federal and federally assisted organizations for the Personal Identity Verification (PIV) FASC-N is the Department of Commerce in coordination with the General Services Administration and the Departments of Homeland Security and Commerce. Federal departments and independent agencies are invited to assist in the maintenance of this publication by submitting copies of newly implemented tables of organization that affect any listing. Such changes should be submitted to the National Institute of Standards and Technology (NIST) via e-mail to piv_comments@nist.gov with "SP 800-87 Update Request " in the subject line.

The two leftmost characters of each code form a component data element which is identical with the twodigit numerical code used in the federal budgetary process to identify major federal organizations. This component, designated as the Treasury Agency Symbol (TAS), is maintained by the U.S. Department of the Treasury; and the National Archives and Records Administration legislatively owns the records.

\subsection{Applicability}

This document is targeted at federal agencies and implementers of PIV systems for the establishment of the PIV FASC-N organizational codes. This publication is not intended for the replacement of U.S. Department of the Treasury agency location and appropriation fund account codes.

\subsection{Organizational Structure}

This publication provides a four-character PIV FASC-N organizational code for each organization listed. The major set of categories used to distinguish groups of organizations in this publication is the following:

- Legislative Branch,

- Judicial Branch,

- Executive Office and Departments (and their Associated Organizations)

- Other Independent federal and Quasi-federal Organizations (and their Associated Organizations)

\footnotetext{
${ }^{1}$ The latest version of Federal Information Processing Standard (FIPS) 201 is FIPS 201-2, Personal Identity Verification (PIV) of Federal Employees and Contractors, National Institute of Standards and Technology, August 2013, 87pp, https://doi.org/10.6028/NIST.FIPS.201-2.
} 
- Independent federal-State and Interstate Organizations

- International Organizations.

Organizational structure is described and encoded in this publication in a manner consistent with the budgetary structure of the U.S. Government. Consistency with the budgetary structure has been maintained in order to permit the adoption of the two-digit numerical code used in the budgetary process to identify most first-level, independent federal organizations. This coding system is maintained by the U.S. Department of the Treasury. Designated as the Treasury Agency Symbol (TAS), it serves as the two leftmost characters of the organization code used in this publication.

All first-level organizations in each of the above categories are listed in this publication. A first-level organization is not subsumed hierarchically under any other organization. Second-level organizations are included with the Executive Office, executive departments, and certain other major agencies. Third- and lower-level organizations are included only in the Department of Defense and in special situations in other departments. Second-, third-, and lower-level organizations are always subsumed hierarchically under a next-higher-level organization.

In this publication, an "independent" organization is defined as having both hierarchical independence and budgetary independence, i.e., it is first-level (hierarchical independence) and has a budget which is not subsumed by or connected in a subsidiary manner with the budget of another organization (budgetary independence). An "associated" organization is first-level, but has no budgetary independence. The five types of associated organizations are:

- Associated federal Organizations, which are federal agencies or their ancillary units such as advisory committees; they are often included as part of the independent organizations to which they are related

- Associated federal-State Organizations, which are associated organizations in which the federal Government and one or more States participate jointly

- Government-Sponsored Enterprises, which are so identified in a separate section of the Budget of the United States Government, Appendix (referred to as The Budget)

- Federally Aided Organizations, which are domestic and non-federal, and are identified in The Budget as receiving some form of financial support such as a direct payment, loan guarantee, line of credit, or stock purchase arrangement

- International Organizations, identified in The Budget or in the Department of State's annual report of United States Contributions to International Organizations as organizations in which the federal Government serves as a financial contributor.

A "quasi-federal" organization is an organization that is listed as "quasi-official" in the U.S. Government Manual and is also assigned its own unique TAS code by the U.S. Department of the Treasury. An "interstate" organization included in this publication is federally assisted but differs from a federal-State organization in that it involves no federal participation.

Associated organizations and organizations below the first level usually carry the same TAS as the independent, first-level organization with which they are connected. Organizations having the same TAS are distinguished from each other by the two rightmost characters of the identifier. These characters are alphanumeric, although numeric characters are being used at this time in most cases. The recommended system used for assignment of the two rightmost characters of the identifier is explained below in Section 4: Special Information. 


\section{Specifications: Table of Organizations and Codes}

\subsection{Part A: Arrangement by Hierarchical and Budgetary Relationship}

In this part, names of first-level organizations are presented immediately to the right of the assigned codes without an indentation.

Second-level organizations are listed immediately below the first-level organization to which they report and are indented further to the right. Second-level organizations which subdivide a first-level organization form a complete, non-duplicative set, i.e., each employee of the first-level organization can be assigned to one and only one second-level entry.

Third- and lower-level organizations are indented further to the right than their respective next-higher level entries, and they are listed immediately below the entry that they subdivide. Third- and lower-level entries, similarly, form a complete, non-duplicative set.

At any level for which entries are provided, some subdivisions may not be individually identified. Those divisions not specifically listed are included by implication, as in "Office of the Assistant Secretary for Health except National Centers."

Each domestic, associated organization is listed with the independent organization with which its financial or administrative support is connected. International organizations are listed in a separate section.

\subsection{Part B: Arrangement by Alphanumeric Sequence of Assigned Codes}

$\underline{\text { Part B }}$ is a listing of organizations and codes arranged by alphanumeric sequence of codes. 


\section{Qualifications}

This document, Special Publication 800-87 (SP 800-87), provides the organizational codes for Federal Agencies to establish the Federal Agency Smart Credential Number (FASC-N) that is required to be included in the FIPS 201 Card Holder Unique Identifier (CHUID). Because FIPS 201 applies only to federal agencies, non-federal organizations were excluded from the requirements of this Special Publication. 


\section{Special Information}

The coding structure in this publication is based on the establishment of four active classes of TAS codes. The assignments of the two rightmost characters of the identifier differ in each of the classes and are described below.

\section{- Defense TAS Codes}

The following TAS codes are used to identify component organizations of the Department of Defense:

17: Department of the Navy;

21: Department of the Army;

57: Department of the Air Force;

84: U.S. Soldiers' and Airmen's Home;

96: U.S. Corps of Engineers--(civil); and

97: Department of Defense as a whole and components, other than the military department, reporting to the Secretary of Defense.

Values of the two rightmost characters of the identifier for all component organizations of the Department of Defense (DoD) are received from the Directorate for Information Resources Management Systems, Office of the Assistant Secretary of Defense (Comptroller). DoD assigns their own codes, usually alphabetic (can be numeric).

- Joint-Use TAS Codes

Several non-Defense, independent organizations share certain TAS codes. These organizations are fully distinguished at the first level by the third and fourth characters of the identifier. The TAS codes in this class, and their applications, are:

00: Senate and House of Representatives;

09: Smaller Legislative Agencies;

10: Judicial Agencies;

46: Independent federal-State and Interstate Organizations (excepting Advisory Commission on Intergovernmental Relations);

48: Temporary Study Commissions;

76: Historical and Memorial Agencies; and

95: Other Independent Organizations Not Assigned Unique TAS Codes.

- TAS Code 11: Executive Office of the President/Funds Appropriated to the President

The Executive Office of the President is assigned identifier 1100, and agencies within the Office are assigned identifiers in the range of 1101 through 1130. The office of the Vice President is assigned 1160.

Agencies that come under the "Funds Appropriated to the President" (FAP) in the federal Budget also are assigned TAS code 11. Currently, two different ranges are used for the two rightmost characters for these FAP agencies. Agencies that are international in scope, such as the Multilateral Development Banks, are assigned alphabetic characters consistent with other international agencies. Other FAP agencies, such as the Peace Corps, are assigned numerics for the two rightmost characters. These currently range from 31 to 62. 
For values of the two rightmost characters of the identifier for associated organizations using TAS code 11, see below under "Single-Use TAS Codes." This class of TAS codes includes all codes that are active (i.e., in current use) and not identified above in another class. As implied in the class name, an independent organization using a TAS code in this class does not share that TAS code with any other independent organization. Second-level, third-level, and associated organizations may be included in this class and will use the same TAS codes as their respective independent organizations.

For each TAS code in this class, the two rightmost characters of the identifier are recommended to be assigned as follows:

00: organization as a whole (always present);

01: office of the chief executive and any staff functions not separately identified;

02: office of the deputy chief executive;

03: office of the general counsel or equivalent;

04: office of the inspector general;

05: office of administration or management, if no "planning" or "policy" functions are included in the name;

06: office of policy, evaluation, or program analysis, including any "budget" functions not included in "administration" or "management";

07: office of Congressional and legislative affairs; may include public or intergovernmental affairs if not separately identified;

08: office of public affairs, if identified separately from Congressional and legislative affairs;

09: office of international affairs;

10 through 29: other staff offices;

30 through 59: programmatic or line organizations, and all of their separately identified, lower-level components;

60 through 69: Associated federal Organizations;

70 through 79: Associated federal-State Organizations;

80 through 89: Government-Sponsored Enterprises;

90 through 99: Federally Aided Organizations; and

AA through ZZ: International Organizations.

For the assignment of the two rightmost characters to international organizations, groupings of such organizations have been established. The third character of the identifier is the same for each organization in a group. This permits recognition of an identifier as pertaining to a particular group. For example, interAmerican organizations have the two rightmost characters of their identifiers in the range AA through AZ; international fisheries organizations are assigned the range FA through FZ, while United Nations and affiliated agencies are assigned the range UA through UZ. This procedure for assigning the two rightmost characters of the identifier is used for each international organization, regardless of the TAS code assigned to the organization.

If expansion of the coding structure is required due to saturation, the fourth or rightmost character of the identifier will be converted to an alphanumeric for staff, line, and domes associated organizations under Single-Use TAS Codes. Then, more identifiers for these types of organizations would be available. For example, in this expansion, the two rightmost characters of identifiers for line organizations under SingleUse TAS Codes could include code $2 \mathrm{~A}$ through $5 \mathrm{Z}$ as well as 20 through 59, while the two rightmost characters for associated federal organizations could include codes $6 \mathrm{~A}$ through $6 \mathrm{Z}$ as well as 60 through 69. This expansion could apply, in a similar fashion, to the coding structure for domestic organization under TAS code 11 or the Joint-Use TAS Codes. 


\section{Table of Organizations and Codes}

\section{Part A: Arrangement by Hierarchical and Budgetary Relationship}




\section{TABLE OF ORGANIZATIONS AND CODES LEGISLATIVE BRANCH}

\section{Code Organization}

0000 THE LEGISLATIVE BRANCH

\section{Congress}

0001 Congress, generally, no additional specification available

0010 Senate, The

0050 House of Representatives, The

0099 Joint House and Senate Entities

(Capitol Police Board, Capitol Guide Service, Office of the Attending Physician, Joint Economic Committee, Joint Committee on Printing, and Joint Committee on Taxation)

\section{Major Legislative Agencies}

0100 Architect of the Capitol

0800 Congressional Budget Office

0500 Government Accountability Office

0501 Comptroller General of the United States

0559 GAO, except Comptroller General

0400 Government Printing Office

0300 Library of Congress

\section{Associated Federal Organizations:}

0361 Library of Congress Trust Fund Board

0363 Federal Library \& Information Center Committee

2300 U.S. Tax Court

9593 U.S. Court of Appeals for Veterans Claims 


\section{TABLE OF ORGANIZATIONS AND CODES LEGISLATIVE BRANCH}

\section{Code Organization}

\section{LEGISLATIVE BRANCH - Continued}

$\underline{\text { Smaller Legislative Agencies }}$

0902 Botanic Garden

0901 Commission on Security and Cooperation in Europe

0914 John C. Stennis Center for Public Service Training and Development

0904 Office of Compliance

0962 Permanent Committee for the Oliver Wendell Holmes Devise

0929 U.S. Capitol Preservation Commission 


\section{TABLE OF ORGANIZATIONS AND CODES JUDICIAL BRANCH}

\section{Code Organization}

1000 THE JUDICIAL BRANCH

1001 Supreme Court of the United States

1050 Chief Justice of the United States

1051 Associate Justices of the Supreme Court

1059 Supreme Court, except Justices

Associated Federal Organization:

1060 Judicial Conference of the United States

1002 U.S. Courts of Appeals-Judicial Circuits (except Federal Circuit)

1003 U.S. Court of Appeals for the Federal Circuit

1004 U.S. Court of International Trade

1005 U.S. Court of Federal Claims

1012 U.S. District and Territorial Courts

1018 U.S. Judicial Panel on Multidistrict Litigation

1021 Bankruptcy Courts

1023 Federal Public Defenders

1025 Court Security

1027 Administrative Office of the U.S. Courts

1028 Federal Judicial Center

1030 United States Sentencing Commission 


\section{TABLE OF ORGANIZATIONS AND CODES EXECUTIVE DEPARTMENTS (and their associated organizations)}

\section{Code Organization}

\section{EXECUTIVE OFFICE OF THE PRESIDENT}

1101 President of the United States

1102 National Security Council

1103 Office of Management and Budget

1121 Director, OMB

1129 OMB, except Director

1105 Office of Administration

1109 Office of the United States Trade Representative

1110 Office of Policy Development

1112 Office of Science and Technology Policy

1113 Council of Economic Advisors

1117 White House Office

1118 Executive Residence at the White House

1119 Council on Environmental Quality/Office of Environmental Quality

1127 Office of the National Drug Control Policy

1160 Office of the Vice President of the United States

1140 President's Council on Sustainable Development

1148 Office of Homeland Security

1170 Commission on the Intelligence Capabilities of the United States Regarding Weapons of Mass Destruction

Associated Federal Organizations:

1165 White House Commission on Presidential Scholars 


\section{TABLE OF ORGANIZATIONS AND CODES EXECUTIVE DEPARTMENTS (and their associated organizations)}

\section{Code Organization}

1200 AGRICULTURE, Department of

1201 Office of the Secretary of Agriculture

12J0 Assistant Secretary for Congressional Relations

12J2 USDA, Office of Congressional and Intergovernmental Relations

1205 USDA, Office of the Chief Financial Officer

1208 USDA, Office of Communications

12A0 USDA, Office of Executive Operations

12A2 USDA, Office of Executive Secretariat

12A4 USDA, Homeland Security

12A5 USDA, Office of the Chief Economist

12A6 USDA, Office of Budget and Program Analysis

12A9 USDA, National Appeals Division

12A7 USDA, Office of the Chief Information Officer

1203 USDA, Office of the General Counsel

1204 Office of the Inspector General

12A8 USDA, Office of Small and Disadvantaged Business

12B1 USDA, Office of Security Services

12B2 USDA, Civil Rights

12B3 USDA, Office of Property and Procurement Management

12B5 USDA, Office of Human Capital Management

12B6 USDA, Office of the Administrative Law Judge

12B7 USDA, Office of the Judicial Officer

12B8 USDA, Board of Contract Appeals

12BD USDA, Office of Ethics

1215 USDA, Office of Operations

12B0 USDA, Assistant Secretary for Administration

12C0 Under Secretary for Natural Resources and Environment

12C2 Forest Service

12C3 Natural Resources Conservation Service

12D0 Under Secretary for Farm and Foreign Agricultural Services

12D2 Farm Service Agency

12D3 Foreign Agricultural Service

12D4 Risk Management Agency

1263 Federal Crop Insurance Corporation

1260 Commodity Credit Corporation

12E0 Under Secretary for Rural Development 


\section{TABLE OF ORGANIZATIONS AND CODES EXECUTIVE DEPARTMENTS (and their associated organizations)}

\section{Code Organization}

1200 AGRICULTURE, Department of - continued

12E2 Rural Utilities Service

1261 Rural Telephone Bank

12E3 Rural Housing Service

12E4 Rural Business Cooperative Service

12E6 National Sheep Industry Improvement Center

12F0 Under Secretary for Food, Nutrition, and Consumer Services

12F2 Food and Nutrition Service

12F3 Center for Nutrition Policy and Promotion

12G0 Under Secretary for Food Safety

12G2 Food Safety and Inspection Service

12H0 Under Secretary for Research, Education, and Economics

12H2 Agricultural Research Service

12H3 Cooperative State Research, Education, and Extension Service

12H4 Economic Research Service

12H5 National Agricultural Statistics Service

12K0 Under Secretary for Marketing and Regulatory Programs

12K2 Agricultural Marketing Service

12K3 Animal and Plant Health Inspection Service

12K4 Grain Inspection, Packers and Stockyards Administration

Federally Aided Organization:

1291 Land grant colleges and Tuskegee Institute 


\section{TABLE OF ORGANIZATIONS AND CODES EXECUTIVE DEPARTMENTS (and their associated organizations)}

\section{Code Organization}

1300 COMMERCE, Department of

1301 Office of the Secretary

1303 Office of the General Counsel

1304 Office of the Inspector General

1306 Office of the Chief Financial Officer \& Assistant Secretary for Administration

1314 Economic and Statistics Administration/Under Secretary for Economic Affairs

Bureau of Economic Analysis

1315

1325

Bureau of the Census

Chief Economist

Economic Development Administration/Assistant Secretary for Economic

Development

1350 International Trade Administration/Under Secretary for International Trade

1351 Under Secretary for Export Administration/Bureau of Industry and Security

1359 Technology Administration/Under Secretary of Technology

1341 National Institute of Standards and Technology

1342 National Technical Information Service

1343 Assistant Secretary for Technology Policy

1330 National Oceanic and Atmospheric Administration/Under Secretary for Oceans and Atmosphere

1335 National Telecommunication and Information Administration/Assistant Secretary for Communications and Information

1344 Patent and Trademark Office/Under Secretary for Intellectual Property

1352 Minority Business Development Agency

\section{Associated Federal Organizations:}

1363 Committee for the Implementation of Textile Agreements

1365 Export Administration Review Board 


\title{
TABLE OF ORGANIZATIONS AND CODES EXECUTIVE DEPARTMENTS (and their associated organizations)
}

\section{Code Organization}

9700 DEFENSE, Department of (except military departments)

Office of the Secretary of Defense and related Organizations

97AD Office of the Secretary of Defense

97EX Office of the Inspector General

97BJ Organization of the Joint Chiefs of Staff

\section{DEFENSE AGENCIES}

\author{
97AE Defense Advanced Research Projects Agency \\ 97JC Missile Defense Agency \\ 9759 Consolidated Metropolitan Technical Personnel Center \\ 97AZ Defense Commissary Agency \\ 97AR Defense Contract Audit Agency \\ 9763 Defense Contract Management Agency \\ 97BZ Defense Finance and Accounting Service \\ 97AK Defense Information Systems Agency \\ 97DL Defense Intelligence Agency \\ 97AV Defense Security Service \\ 97AQ Defense Legal Services Agency \\ 97AS Defense Logistics Agency \\ 97AB National Geospatial-Intelligence Agency \\ 97AT Defense Security Cooperation Agency \\ 97CG National Security Agency/Central Security Service \\ 9761 Defense Threat Reduction Agency \\ 9762 Defense Career Management and Support Agency \\ 9765 Pentagon Force Protection Agency
}

Field Activities of the Department of Defense

97F1 American Forces Information Service

9758 Defense Prisoner of War/Missing Personnel Office

97AU Defense Technology Security Administration

9748 Defense Human Resources Activity

97F2 Department of Defense Education Activity

97F6 Office of Economic Adjustment

97F5 Washington Headquarters Services

9760 TRICARE Management Activity 


\section{TABLE OF ORGANIZATIONS AND CODES EXECUTIVE DEPARTMENTS (and their associated organizations)}

\section{Code Organization}

9700 DEFENSE, Department of (except military departments) - continued

9766 Department of Defense Counterintelligence Field Activity

9774 Defense Technical Information Center

Other Activities/Organizations

97GZ U.S. Court of Appeals for the Armed Forces

9736 Army/Air Force Exchange Service

$9767 \quad$ Unified Combatant Command Headquarters

$9769 \quad$ National Defense University

9770 Armed Forces Radiobiology Research Institute

9771 Defense Microelectronics Activity

9772 Pentagon Renovation Program Office

$9773 \quad$ Virginia Contracting Activity 


\section{TABLE OF ORGANIZATIONS AND CODES EXECUTIVE DEPARTMENTS (and their associated organizations)}

\section{Code Organization}

5700 AIR FORCE, Department of the (Headquarters, USAF)

5701 Air Force Management Engineering Agency

5702 Air Force Inspection and Safety Center

5703 Air Force Operational Test and Evaluation Center

5704 Air Force Communications Agency

5705 Air Force Intelligence Service

$5706 \quad$ Air Force Audit Agency

5707 Air Force Office of Special Investigations

5708 Air Force Office of Security Police

5709 Air Force Personnel Center

5711 Air Force Manpower Agency

570B U.S. Air Force Academy

570D U.S. Air Forces, Europe

570J Air Training Command

570K Air University

570M Headquarters, Air Force Reserve

570N Immediate Office, Headquarters, USAF

570R Pacific Air Forces

570U Air Force Headquarters Air Intelligence Agency

570Y Air Force Communications Command

571A Air Force C2 \& Intelligence, Surveillance \& Reconnaissance

571C Air Combat Command

571G Air Force Logistics Management Agency

571L Air Mobility Command

571M Air Force Materiel Command

5710 Air Force Center for Quality and Management Innovation

571P Air Force Real Property Agency

571Q HQ AF Flight Standards Agency

571S Space Command

571W Air Force Engineering and Services Center

5727 Air Force Agency for Modeling and Simulation

5728 Air Force Communication and Information Center

5729 Air Force National Security Emergency Preparedness

572A Air Force Cost Center

572B Air Force Doctrine Center

572C Air Force Civilian Personnel Management Center

572D Air Force Personnel Operations Agency

572E Air Force Legal Services Center 


\section{TABLE OF ORGANIZATIONS AND CODES EXECUTIVE DEPARTMENTS (and their associated organizations)}

\section{Code Organization}

5700 AIR FORCE, Department of the (Headquarters, USAF) - continued

\begin{tabular}{|c|c|}
\hline $572 \mathrm{~F}$ & Air Force Medical Services Center \\
\hline $572 \mathrm{G}$ & Air Force Service Information and News Center \\
\hline $572 \mathrm{H}$ & Air Force Combat Operations Staff \\
\hline $572 \mathrm{~K}$ & U.S. Air Force Historical Research Center \\
\hline 572L & Air Force Technical Applications Center \\
\hline $572 \mathrm{M}$ & Air Force Review Boards Office \\
\hline $572 \mathrm{~N}$ & Air Force Center for Studies and Analyses \\
\hline $572 \mathrm{P}$ & Air Force Center for International Programs \\
\hline $572 Q$ & Air Weather Service \\
\hline $572 \mathrm{R}$ & Air Force Program Executive Office \\
\hline $572 S$ & HQ NORAD \\
\hline $572 \mathrm{~T}$ & Air Force Supply Center \\
\hline $572 \mathrm{U}$ & Air Force Morale, Welfare and Recreation Center \\
\hline $572 \mathrm{~V}$ & Air Force Disposal Agency \\
\hline $572 \mathrm{~W}$ & Air Force District of Washington \\
\hline $572 X$ & Air Force Real Estate Agency \\
\hline $572 Y$ & Air Force Pentagon Communications Agency \\
\hline $572 Z$ & HQ Air Force Medical Operations Agency \\
\hline $573 \mathrm{C}$ & Air Force Elements, U.S. Central Command \\
\hline 573D & Air Force Elements, U.S. Special Operations Command \\
\hline $573 G$ & Air Force Elements, Europe \\
\hline $573 \mathrm{I}$ & Reservist, Centrally Managed \\
\hline $573 \mathrm{~K}$ & HQ U.S. European Command \\
\hline 573L & Center for Air Force History \\
\hline $573 \mathrm{M}$ & Air Force Elements, U.S. Southern Command \\
\hline $573 N$ & Air Force Elements, U.S. Atlantic Command \\
\hline 5730 & Air Force Elements, U.S. Pacific Command \\
\hline $573 Q$ & Air Force Elements, U.S. Strategic Command \\
\hline 573R & Air Force Elements, U.S. Readiness Command \\
\hline 573S & Headquarters, U.S. Space Command and NORAD \\
\hline $573 \mathrm{~T}$ & Air Force Elements U.S. Transportation Command \\
\hline $573 \mathrm{~V}$ & Air Force Elements, Other than Europe \\
\hline 573W & Air Force Center for Environmental Excellence \\
\hline $573 Y$ & Air Force Frequency Management Center \\
\hline $573 Z$ & Joint Services Survival, Evasion, Resistance and Escape Agency \\
\hline
\end{tabular}




\section{TABLE OF ORGANIZATIONS AND CODES EXECUTIVE DEPARTMENTS (and their associated organizations)}

\section{Code Organization}

5700 AIR FORCE, Department of the (Headquarters, USAF) - continued

574Z Air National Guard

572I

Air National Guard Support Center

5734

Air National Guard Units (Mobilization) (Title 5)

$57 \mathrm{NG}$

Air National Guard Units (Title 32)

$57 Z G$

U.S. Special Operations Command (ANG Title 32)

$57 Z S$

U.S. Special Operations Command (Air Force)

570I

Air Reserve Personnel Center 


\section{TABLE OF ORGANIZATIONS AND CODES EXECUTIVE DEPARTMENTS (and their associated organizations)}

\section{Code Organization}

2100 ARMY, Department of the (except Corps of Engineers Civil Program Financing)

21SA Office of the Secretary of the Army

21SB Field Operating Offices of the Office of the Secretary of the Army

21SE Field Operating Agencies of the Army Staff Resourced through OA-22

21SF Field Operating Agencies of the Army Staff

21SJ Joint Services and Activities Supported by the Office, Secretary of the Army

21 G6 U.S. Army Network Enterprise Technology Command/9th Army Signal

Command

Office of the Chief of Staff of the Army

21CS Immediate Office of the Chief of Staff of the Army

21BA U.S. Army Installation Management Agency

21AE Acquisition Executive Support Command Agency

21P8 Eighth U.S. Army

21JA Joint Activities

21PC Military Entrance Processing Command

21MT Military Traffic Management Command

$2130 \quad$ National Guard Bureau

21GB Office of the Chief of the National Guard Bureau

$21 \mathrm{NG}$

$21 \mathrm{MD}$

Army National Guard Units (Title 32)

21AU

Surgeon General

21CE

U.S. Army Audit Agency

96CE

21CB

21J1

U.S. Army Corps of Engineers, except civil program financing

U.S. Army Corps of Engineers - civil program financing only

U.S. Army Criminal Investigation Command

U.S. Army Element SHAPE

21E1

U.S. Army Europe and Seventh Army Immediate Office of the Commander-In-Chief of the U.S. Army

Europe and Seventh Army

21E2

21st Theater Army Area Command

$21 \mathrm{E} 3$

U.S. Army Southern European Task Force

U.S. Army V Corps

1st Personnel Command

U.S. Military Community Activity, Heidelberg

Seventh Army Training Command 


\section{TABLE OF ORGANIZATIONS AND CODES EXECUTIVE DEPARTMENTS (and their associated organizations)}

\section{Code Organization}

2100 ARMY, Department of the

(except Corps of Engineers Civil program financing) - continued

Office of the Chief of Staff of the Army - Continued

$\begin{array}{ll}21 \mathrm{EO} & \text { 59th Ordnance Brigade } \\ 21 \mathrm{FC} & \text { U.S. Army Forces Command } \\ 21 \mathrm{HS} & \text { U.S. Army Health Services Command } \\ 21 \mathrm{CZ} & \text { U.S. Army Information Systems Command } \\ 21 \mathrm{AS} & \text { U.S. Army Intelligence and Security Command } \\ & \\ 21 \mathrm{X} 1 & \text { U.S. Army Materiel Command (AMC) } \\ 21 \mathrm{X} 2 & \text { Headquarters, Army Materiel Command } \\ 21 \mathrm{X} 3 & \text { Headquarters, Staff Support Activities, AMC } \\ 21 \mathrm{XK} & \text { Materiel Acquisition Activities } \\ 21 \mathrm{XL} & \text { Materiel Acquisition Project Managers } \\ 21 \mathrm{XX} & \text { Materiel Readiness Activities } \\ 21 \mathrm{XR} & \text { U.S. Army Research, Development and Engineering Command } \\ 21 \mathrm{X} 4 & \text { Training Activities, AMC } \\ 21 \mathrm{XA} & \text { U.S. Army Chemical and Biological Defense Command } \\ 21 \mathrm{XB} & \text { U.S. Army Chemical Materials Command } \\ 21 \mathrm{X} 8 & \text { U.S. Army Communications Electronics Command } \\ 21 \mathrm{XQ} & \text { U.S. Army Operations Support Command } \\ 21 \mathrm{X} 5 & \text { U.S. Army Materiel Command, all others } \\ 21 \mathrm{X} 6 & \text { U.S. Army Missile Command } \\ 21 \mathrm{XD} & \text { U.S. Army Research Laboratory Command } \\ 21 \mathrm{XP} & \text { U.S. Army Security Assistance Command } \\ 21 \mathrm{X} 9 & \text { U.S. Army Simulation, Training and Instrumentation Command } \\ 21 \mathrm{XC} & \text { U.S. Army Soldiers System Command (SSC) } \\ 21 \mathrm{X} 7 & \text { U.S. Army Tank-Automotive and Armament Command (TACOM) } \\ 21 \mathrm{XT} & \text { U.S. Army Test, Measurement, and Diagnostic Equipment Activity } \\ & \\ 21 \mathrm{MC} & \text { U.S. Army Medical Command } \\ 21 \mathrm{MW} & \text { U.S. Army Military District of Washington } \\ 21 \mathrm{RC} & \text { U.S. Army Recruiting Command } \\ & \end{array}$




\section{TABLE OF ORGANIZATIONS AND CODES EXECUTIVE DEPARTMENTS (and their associated organizations)}

\section{Code Organization}

2100 ARMY, Department of the

(except Corps of Engineers Civil program financing) - continued

Office of the Chief of Staff of the Army - continued

21HR U.S. Army Reserve Command

21SU U.S. Army Southern Command

21FL U.S. Army South Command

21SC U.S. Army Space and Strategic Defense Command

21AT U.S. Army Test and Evaluation Command

21TC U.S. Army Training and Doctrine Command

21P1 U.S. Army, Pacific

21MA U.S. Military Academy

21SP U.S. Special Operation Command (Army)

21MP U.S. Army Human Resources Command

21SS Staff Support Agencies of the Chief of Staff, Army

Associated Federal Organization:

9668 Mississippi River Commission 


\section{TABLE OF ORGANIZATIONS AND CODES EXECUTIVE DEPARTMENTS (and their associated organizations)}

\section{Code Organization}

1700 NAVY, Department of the

1712 Navy Secretariat/Staff Offices

1708 Immediate Office of the Secretary of the Navy

$1710 \quad$ Navy Field Offices

$1709 \quad$ Navy Staff Offices

1714 Office of Naval Research

Chief of Naval Operations

1711 Immediate Office of the Chief of Naval Operations

$1715 \quad$ Naval Intelligence Command

1718 Naval Medical Command

1719 Naval Air Systems Command

1722 Bureau of Naval Personnel

$1723 \quad$ Naval Supply Systems Command

$1724 \quad$ Naval Sea Systems Command

1725 Naval Facilities Engineering Command

1730 Special Projects Office

1733 Military Sealift Command

1739 Naval Space and Warfare Systems Command

1741 Naval Systems Management Activity

1752 Commander, Navy Installations

$1760 \quad$ U.S. Atlantic Fleet, Commander In Chief

$1761 \quad$ U.S. Naval Forces, Europe

1762 Chief of Naval Education and Training

1763 Naval Network Operations Command

1765 Naval Oceanography Command

1769 Naval Security Group Command

1770 U.S. Pacific Fleet, Commander in Chief

1772 Naval Reserve Force

1774 Naval Special Warfare Command

17ZS U.S. Special Operations Command (Navy)

1776 Naval Education and Training Command

1727 U.S. Marine Corps 


\section{TABLE OF ORGANIZATIONS AND CODES EXECUTIVE DEPARTMENTS (and their associated organizations)}

\section{Code Organization}

9100 EDUCATION, Department of

9101 Immediate Office of the Secretary of Education

9102 Office of the Deputy Secretary of Education

9108 Office of the Under Secretary

9103 Office of the General Counsel

9104 Office of Inspector General

9105 Office of Management

9115 Office of the Chief Information Officer

9106 Office of the Chief Financial Officer

9107 Office of Legislation and Congressional Affairs

9109 Office of Communications and Outreach

9110 Office of Planning, Evaluation and Program Development

9111 Office for Civil Rights

9121 Office of English Language Acquisition

9139 Institute of Education Sciences

9132 Immediate Office of the Director of Education Sciences

$9138 \quad$ National Center for Education Statistics

$9135 \quad$ National Center for Education Research

9137

9136

9131

9146

9141

National Center for Educational Evaluation and Regional Assistance

National Center for Special Education Research

Federal Student Aid

Office of Elementary and Secondary Education

Immediate Office of the Assistant Secretary for Elementary and Secondary Education

9140

9145

9142

9144

9143

9147

9134

9130

9129

9133

9124

9128

Student Achievement and School Accountability Program

Office of Indian Education

Migrant Education Programs

$$
\text { Impact Aid Programs }
$$

School Support and Technology Programs

Academic Improvement and Teacher Quality Programs

Office of Postsecondary Education

Immediate Office of the Assistant Secretary for Postsecondary Education

Fund for the Improvement of Postsecondary Education

Office of Higher Education Programs

Office of Special Education and Rehabilitative Services

Immediate Office of the Assistant Secretary for Special Education and Rehabilitative Services

9125

9126

National Institute on Disability and Rehabilitation Research

Rehabilitation Services Administration 


\section{TABLE OF ORGANIZATIONS AND CODES EXECUTIVE DEPARTMENTS (and their associated organizations)}

\section{Code Organization}

9100 EDUCATION, Department of - continued

9127 Office of Special Education Programs

9120 Office of Vocational and Adult Education

9150 Office of Innovation and Improvement

9155 Office of Safe and Drug-Free Schools

Associated Federal Organizations:

916A Advisory Councils and Committees

916B National Assessment Governing Board

916C National Institute for Literacy

916D Federal Interagency Committee on Education

Government-Sponsored Enterprise:

9181 Student Loan Marketing Association (Sallie Mae)

9182 College Construction Loan Insurance Association (Connie Lee)

Federally Aided Organizations:

9191 American Printing House for the Blind

9192 Gallaudet University

9193 Howard University

9194 National Technical Institute for the Deaf 


\section{TABLE OF ORGANIZATIONS AND CODES EXECUTIVE DEPARTMENTS (and their associated organizations)}

\section{Code Organization}

8900 ENERGY, Department of

8901 Office of the Secretary

8903 Office of General Counsel

8904 Office of Inspector General

893C Office of the Chief Financial Officer

891N Office of Chief Information Officer

8905 Assistant Secretary for Congressional and Intergovernmental Affairs

$8915 \quad$ Office of Public Affairs

8938 Assistant Secretary for Policy and International Affairs

891C Office of Economic Impact and Diversity

$8906 \quad$ Office of Hearings and Appeals

893H Office of Human Capital Management

8929 Office of Intelligence

892E Office of the Secretary of Energy Advisory Board

891H Office of Health, Safety and Security

893M Office of Management

$892 \mathrm{H}$ Office of Counterintelligence

892L Office of Electricity Delivery and Energy Reliability

8932 Office of Energy Information Administration

8936 Office of Legacy Management

891S Office of the Departmental Representative to the Defense Nuclear Facilities Safety Board

8921 Assistant Secretary for Energy Efficiency and Renewable Energy

8911 Office of Civilian Radioactive Waste Management

8917 Assistant Secretary for Environmental Management

8928 Assistant Secretary for Fossil Energy

8927 Office of Nuclear Energy, Science and Technology

$\underline{\text { National Nuclear Security Administration (NNSA) }}$

89NA Office of the National Nuclear Security Administrator

89N0 Deputy Under Secretary for Counterterrorism

89N2 Deputy Administrator for Defense Nuclear Nonproliferation

89N1 Deputy Administration for Defense Programs

89N3 Deputy Administrator for Naval Reactors

89N4 Office of Emergency Operations

89N5 Associate Administrator for Facilities and Operations 


\section{TABLE OF ORGANIZATIONS AND CODES EXECUTIVE DEPARTMENTS (and their associated organizations)}

\section{Code Organization}

8900 ENERGY, Department of - continued

89N6 Associate Administrator for Management and Administration

89N7 Associate Administrator for Defense Nuclear Security

89NW Oakland Operations Office (NNSA) (EM)

89X1 Pittsburgh Naval Reactors

89X2 Schenectady Naval Reactors

89XQ Y-12 Site Office

89XR Pantex Site Office

89XS Sandia Site Office

89XT Kansas City Site Office

89XU Los Alamos Site Office

89XV Nevada Site Office

89XW Livermore Site Office

89SV Savannah River Site Office

89ZA National Nuclear Security Administration Service Center

Power Marketing Administrations:

89BP Bonneville Power Marketing Administration

89SE Southeastern Power Marketing Administration

89SW Southwestern Power Marketing Administration

89WA Western Area Power Marketing Administration

$8925 \quad$ Office of Science

$\underline{\text { Site Offices }}$

89BC Ames Site Office

89BD Argonne Site Office

89BE Berkeley Site Office

89BF Brookhaven Site Office

89BA Chicago Office

89BG Fermi Site Office

89BB Oak Ridge Office

89BH Pacific Northwest Site Office

89BI Princeton Site Office

89BJ Stanford Site Office

89BK Thomas Jefferson Site Office 


\section{TABLE OF ORGANIZATIONS AND CODES EXECUTIVE DEPARTMENTS (and their associated organizations)}

\section{Code Organization}

$8900 \quad$ ENERGY, Department of - continued

\section{Field Offices:}

89AL Albuquerque Operations Office (non-NNSA) (EM)

89CB Carlsbad Field Office

$8981 \quad$ Casper Naval Pet \& Oil Shale Reserves

8955 Consolidated Business Center

$8982 \quad$ Elk Hills Naval Pet \& Oil Shale Reserves

89GO Golden Field Office

89ID Idaho Operations Office

89NV Nevada Operations Office (non-National Nuclear Security Administration) (Environmental Management)

89NE National Energy Technology Laboratory

89RP Office of River Protection

89OH Ohio Field Office

89PP Portsmouth \& Paducah Project Office

89RL Richland Operations Office

89RF Rocky Flats Project Office

89SR Savannah River Operations Office

$8974 \quad$ Strategic Petroleum Reserves

Associated Federal Organizations:

8990 Federal Energy Regulatory Commission 


\section{TABLE OF ORGANIZATIONS AND CODES EXECUTIVE DEPARTMENTS (and their associated organizations)}

\section{Code Organization}

7500 HEALTH AND HUMAN SERVICES, Department of

750S Office of the Secretary of Health and Human Services

7501 Immediate Office of the Secretary of Health and Human Services

7502 Office of the Deputy Secretary of Health and Human Services

7503 Office of the General Counsel

$7504 \quad$ Office of the Inspector General

7505 Office of Assistant Secretary for Administration and Management

7506 Office of Assistant Secretary for Planning and Evaluation

7507 Office of Assistant Secretary for Legislation

7508 Office of Assistant Secretary for Public Affairs

$7511 \quad$ Office for Civil Rights

7512 Office of Assistant Secretary for Public Response

7521 Office of the Surgeon General

7515 Office of Public Health and Science

7509 Office of Intergovernmental Affairs and Regional Directors

7510 Office of the Assistant Secretary for Resources and Technology

7516 Departmental Appeals Board

$7520 \quad$ Public Health Service

7522 Substance Abuse and Mental Health Services Administration

$7523 \quad$ Centers for Disease Control and Prevention

$7524 \quad$ Food and Drug Administration

$7525 \quad$ Agency for Toxic Substances and Disease Registry

$7526 \quad$ Health Resources and Services Administration

7527 Indian Health Service

7528 Agency for Healthcare Research and Quality

$7529 \quad$ National Institutes of Health

7530 Centers for Medicare \& Medicaid Services

7545 Administration on Aging

7590 Administration for Children and Families

7555 Program Support Center 


\section{TABLE OF ORGANIZATIONS AND CODES EXECUTIVE DEPARTMENTS (and their associated organizations)}

\section{Code Organization}

7000 HOMELAND SECURITY, Department of

7001 Office of the Secretary, Department of Homeland Security

$7002 \quad$ Immediate Office of the Secretary

$7003 \quad$ U.S. Citizenship and Immigration Services

7004 Office of the Inspector General

$7008 \quad$ U.S. Coast Guard

7009 U.S. Secret Service

$7012 \quad$ U.S. Immigration and Customs Enforcement

7013 Transportation Security Administration

$7014 \quad$ U.S. Customs and Border Protection

7015 Federal Law Enforcement Training Center

7022 Federal Emergency Management Agency

$7032 \quad$ Office for Information Analysis

7033 Office for Infrastructure Protection

7040 Under Secretary for Science and Technology

7041 Office of the Under Secretary for Science and Technology

7050 Under Secretary for Management

7051 Office of the Under Secretary for Management 


\section{TABLE OF ORGANIZATIONS AND CODES EXECUTIVE DEPARTMENTS (and their associated organizations)}

\section{Code Organization}

8600 HOUSING AND URBAN DEVELOPMENT, Department of

8601 Office of the Secretary of Housing and Urban Development

8602 Deputy Secretary of Housing and Urban Development

8613 HUD Board of Contract Appeals

8615 Office of Administrative Law Judges

8617 Office of Small and Disadvantaged Business Utilization

8622 Assistant Deputy Secretary for Field Policy and Management

8603 Office of General Counsel

8604 Office of Inspector General

8605 Assistant Secretary for Administration

8606 Office of Chief Financial Officer

8607 Assistant Secretary for Congressional and Intergovernmental Relations

8608 Assistant Secretary for Public Affairs

8611 Assistant Secretary for Fair Housing and Equal Opportunity

8620 Assistant Secretary for Community Planning and Development

8630 Assistant Secretary for Housing--Federal Housing Commissioner

8635 Assistant Secretary for Public and Indian Housing

8645 Assistant Secretary for Policy Development and Research

8625 Government National Mortgage Association (Ginnie Mae)

8653 Office of Healthy Homes and Lead Hazard Control

8654 Office of the Chief Procurement Officer

8627 Office of Departmental Equal Employment Opportunity

8651 Office of Departmental Operations and Coordination

8652 Office of the Chief Information Officer

8658 Center for Faith-based and Community Initiatives

8659 Office of Field Policy and Management

865A Office of the Field Policy and Management Region I, Boston Regional

Office

865B Office of the Field Policy and Management Region II, New York Regional Office

865C Office of the Field Policy and Management Region III, Philadelphia Regional Office 


\section{TABLE OF ORGANIZATIONS AND CODES EXECUTIVE DEPARTMENTS (and their associated organizations)}

\section{Code Organization}

8600 HOUSING AND URBAN DEVELOPMENT, Department of - continued

865D Office of Field Policy and Management Region IV, Atlanta Regional Office 865E Office of Field Policy and Management Region V, Chicago Regional Office 865F Office of Field Policy and Management Region VI, Fort Worth Regional Office 865G Office of Field Policy and Management Region VII, Kansas City Regional Office 865H Office of Field Policy and Management Region VIII, Denver Regional Office 865J Office of Field Policy and Management Region IX, San Francisco Regional Office

865K Office of Field Policy and Management Region X, Seattle Regional Office Government-Sponsored Enterprise:

8681 Federal National Mortgage Association (Fannie Mae)

8683 Federal Home Loan Mortgage Corporation (Freddie Mac) 


\section{TABLE OF ORGANIZATIONS AND CODES EXECUTIVE DEPARTMENTS (and their associated organizations)}

\section{Code Organization}

1400 INTERIOR, Department of the

1401 Office of the Secretary of the Interior

1402 Office of the Deputy Secretary of the Interior

1406 Office of Policy, Management and Budget/Chief Financial Officer

$1413 \quad$ Office of Hearings and Appeals

1418 Office of Small and Disadvantaged Business Utilization

1410 Office of the Chief Information Officer

1407 Office of Congressional and Legislative Affairs

1408 Office of Communications

1409 Office of Insular Affairs

1411 Office for Equal Opportunity

1414 Executive Secretariat \& Office of Regulatory Affairs

1415 Office of the Special Trustee for American Indians

1416 Office of Historic Trust Accounting

1403 Office of the Solicitor

1404 Office of the Inspector General

1428 National Business Center

142F Fish and Wildlife and Parks (Assistant Secretary)

$1443 \quad$ National Park Service

$1448 \quad$ U.S. Fish and Wildlife Service

1450 Indian Affairs (Assistant Secretary)

142L Land and Minerals Management (Assistant Secretary)

1422 Bureau of Land Management

1435 Bureau of Ocean Energy Management

1436 Bureau of Safety and Environmental Enforcement

1438 Office of Surface Mining, Reclamation and Enforcement

142W Water and Science (Assistant Secretary)

1425 Bureau of Reclamation

1434 Geological Survey 


\section{TABLE OF ORGANIZATIONS AND CODES EXECUTIVE DEPARTMENTS (and their associated organizations)}

\section{Code Organization}

1400 INTERIOR, Department of - continued

Associated Federal Organizations:

1460 Board on Geographic Names

1464 Illinois and Michigan Canal National Heritage Corridor Commission

1465 Metropolitan River Corridors Study Committee

1461 Migratory Bird Conservation Commission

1469 National Indian Gaming Commission

1467 Utah Reclamation Mitigation and Conservation Commission

1468 Indian Arts and Crafts Board

1466 Endangered Species Committee 


\section{TABLE OF ORGANIZATIONS AND CODES EXECUTIVE DEPARTMENTS (and their associated organizations)}

\section{Code Organization}

1500 JUSTICE, Department of

1501 Offices, Boards and Divisions (includes the following: Associate Attorney General, Office of Policy Development, , Office of Intelligence Policy and Review, and Office of Information and Privacy)

1502 Civil Division

1503 Criminal Division

1504 Office of the Inspector General

1505 Civil Rights Division

1506 Environment and Natural Resources Division

1507 Foreign Claims Settlement Commission

1508 Justice Management Division

1509 Office of the Assistant Attorney General

1510 Office of the Attorney General

1511 Office of the Deputy Attorney General

1512 Office of Information Policy

1513 Office of Legislative Affairs

1514 Office of Legal Counsel

1515 Office of the Pardon Attorney

1516 Office of Professional Responsibility

1517 Office of the Solicitor General

1518 Office of Public Affairs

1519 Tax Division

1520 United States National Central Bureau

1521 United States Parole Commission

1522 Community Oriented Policing Services

1523 National Drug Intelligence Center

1524 Drug Enforcement Administration

1525 National Security Division

1526 Executive Office for U.S. Attorneys and the Offices of U.S. Attorneys

1527 Office of Dispute Resolution

1528 Immigration and Naturalization Service

1529 Office of Intergovernmental and Public Liaison

1530 Executive Office for Immigration Review

1531 Office of Legal Policy

1532 Office on Violence Against Women

1533 Professional Responsibility Advisory Office 


\section{TABLE OF ORGANIZATIONS AND CODES EXECUTIVE DEPARTMENTS (and their associated organizations)}

\section{Code Organization}

1500 JUSTICE, Department of - continued

1535 Community Relations Service

1536 Antitrust Division

1537 Office of the Federal Detention Trustee

1538 Office of Privacy and Civil Liberties

1540 Bureau of Prisoners/Federal Prison System

1544 U.S. Marshals Service

1549 Federal Bureau of Investigation

1550 Office of Justice Programs

(includes the following: Bureau of Justice Assistance, Bureau of Justice Statistics, National Institute of Justice, Office for Victims of Crimes, Office of Juvenile Justice and Delinquency Prevention, and Executive Office for Weed and Seed)

1555 Executive Office for U.S. Trustee

1560 Bureau of Alcohol, Tobacco, Firearms and Explosives 


\section{TABLE OF ORGANIZATIONS AND CODES EXECUTIVE DEPARTMENTS (and their associated organizations)}

\section{Code Organization}

1600 LABOR, Department of

160S Office of the Secretary of Labor

1601 Immediate Office of the Secretary of Labor

160U Office of the Deputy Secretary of Labor

1610 Office of Adjudicatory Service

1613 Office of Administrative Law Judges

1615 Benefits Review Board

1616 Employees Compensation Appeals Board

1617 Administrative Review Board

1618 Office of Small Business Programs

1619 Executive Secretariat

1620 Office of $21^{\text {st }}$ Century Workforce

1623 Center for Faith-based and Community Initiatives

1607 Office of the Assistant Secretary of Labor for Congressional and Intergovernmental Affairs

1608 Office of Public Affairs

1655 Women's Bureau

1609 Bureau of International Labor Affairs

1603 Office of the Solicitor

1604 Office of Inspector General

1605 Office of the Assistant Secretary for Administration and Management

1622 Office of the Chief Financial Officer

1606 Office of the Assistant Secretary for Policy

1625 Bureau of Labor Statistics

1631 Office of Job Corps

1630 Employment and Training Administration

1635 Employment Standards Administration

1645 Mine Safety and Health Administration

1650 Occupational Safety and Health Administration

1621 Employee Benefits Security Administration

1653 Veterans Employment and Training Services

1667 Office of Disability Employment Policy

$\underline{\text { Associated Federal Organizations: }}$

1665 Pension Benefit Guaranty Corporation 


\section{TABLE OF ORGANIZATIONS AND CODES EXECUTIVE DEPARTMENTS (and their associated organizations)}

\section{Code Organization}

1900 STATE, Department of

190S Office of the Secretary of State

1901 Immediate Office of the Secretary of State

1902 Office of the Deputy Secretary of State

1858 Office of U.S. Ambassador to the United Nations

1906 Policy Planning Council

1907 Bureau of Legislative Affairs

1910 Chief of Protocol

1911 Office of Equal Employment Opportunity and Civil Rights

1912 Coordinator for Counter-Terrorism

1917 Executive Secretary

1904 Office of the Inspector General

1939 Bureau of Intelligence and Research

1903 Office of the Legal Adviser

1916 Counselor of the Department

1918 Chief of Staff

1905

1930

1931

1932

1935

1937

1938

1943

1934

1946

1913 Office of the Under Secretary for Political Affairs

1921

1923

Bureau of African Affairs

1925

Bureau of East Asian and Pacific Affairs

1927

Bureau of European and Eurasian Affairs

1928

Bureau of Western Hemisphere Affairs

1929

Bureau of South Asian Affairs

1945

Bureau of Near Eastern Affairs

Bureau of International Organization Affairs 


\section{TABLE OF ORGANIZATIONS AND CODES EXECUTIVE DEPARTMENTS (and their associated organizations)}

\section{Code Organization}

1900 STATE, Department of - continued

1914 Office of the Under Secretary for Economic and Agricultural Affairs

1933 Bureau of Economic and Business Affair

1934 Bureau of Overseas Buildings Operations

1915 Office of the Under Secretary for Arms Control and International Security Affairs

$1950 \quad$ Bureau of Political-Military Affairs

1951 Assistant Secretary for Arms Control

1955 Assistant Secretary for Non-Proliferation

1956 Assistant Secretary for Verification and Compliance

19TB Office of the Under Secretary for Public Diplomacy and Public Affairs

$1952 \quad$ Bureau of Public Affairs

1953 Bureau of Educational and Cultural Affairs

1957 International Public Information Core Group Secretariat

1959 Office of International Information Programs

1941 Office of the Under Secretary for Global Affairs

1936 Bureau of Democracy, Human Rights and Labor

1942 Bureau of International Narcotics and Law Enforcement Affairs

1948 Bureau of Oceans and International Environmental and Scientific Affairs

1954 Bureau of Population, Refugees and Migration

Associated Federal Organization:

1960 Artistic Ambassador Advisory Committee

1961 Board of Foreign Scholarships

1962 Cultural Property Advisory Committee

1963. U.S. Advisory Commission on Public Diplomacy

1964 J. William Fulbright Foreign Scholarship Board

1965 Center for Cultural and Technical Interchange between East and West

1966 Eastern Europe Student Exchange Program

1967 Center for Cultural and Technical Interchange between North and South

1968 Russian Far East Technical Assistance Center

1969 National Endowment for Democracy

195A Eisenhower Exchange Fellowship Program

195B Israeli Arab Scholarship Program 


\section{TABLE OF ORGANIZATIONS AND CODES EXECUTIVE DEPARTMENTS (and their associated organizations)}

\section{Code Organization}

1900 STATE, Department of -continued

\section{Associated Federal Organization -continued:}

195C Broadcasting Board of Governors

19BC U.S. and Canada International Boundary Commission

19BJ U.S. and Canada International Joint Commission

19BM U.S. and Mexico International Boundary and Water Commission

19BE U.S. and Canada Border Environment Cooperation Commission

NOTE: Agencies (19BC-19BE) are listed under International

Organizations, this secondary listing is for user convenience only.

Federally Aided Organizations:

1991 American Institute in Taiwan

1993 Asia Foundation 


\section{TABLE OF ORGANIZATIONS AND CODES EXECUTIVE DEPARTMENTS (and their associated organizations)}

\section{Code Organization}

6900 TRANSPORTATION, Department of

690S Office of the Secretary of Transportation

6904 Office of Inspector General

6920 Federal Aviation Administration

6925 Federal Highway Administration

6930 Federal Railroad Administration

6938 Maritime Administration

6940 National Highway Traffic Safety Administration

6943 Research and Innovative Technology Administration

6947 Saint Lawrence Seaway Development Corporation

6953 Federal Motor Carrier Safety Administration

6955 Federal Transit Administration

6957 Pipeline and Hazardous Materials Safety Administration

Associated Federal Organizations:

6959 Surface Transportation Board

NOTE: This agency was formerly the Interstate Commerce Commission, which had been assigned code 3000 .

Federally Aided Organization:

6991 National Railroad Passenger Corporation (AMTRAK) 


\section{TABLE OF ORGANIZATIONS AND CODES EXECUTIVE DEPARTMENTS (and their associated organizations)}

\section{Code Organization}

2000 TREASURY, Department of the

2001 Departmental Offices

2004 Inspector General

2014 Office of the Inspector General for Tax Administration

2046 Office of the Comptroller of the Currency

2041 Bureau of Engraving and Printing

2042 Bureau of the Fiscal Service

2044 United States Mint

2022 Alcohol and Tobacco Tax and Trade Bureau

2026 Financial Crimes Enforcement Network

2050 Internal Revenue Service

$\underline{\text { Associated Federal Organizations: }}$

$2061 \quad$ Federal Financing Bank

2066 Community Development Financial Institutions

Federally Aided Organizations:

2093 District of Columbia

2094 District of Columbia Public School 


\section{TABLE OF ORGANIZATIONS AND CODES EXECUTIVE DEPARTMENTS (and their associated organizations)}

\section{Code Organization}

3600 VETERANS AFFAIRS, Department of

3601 Office of the Secretary

$3602 \quad$ Office of the Deputy Secretary

3615 Center for Minority Veterans

$3616 \quad$ Center for Women Veterans

3617 Office of Employment Discrimination Complaint Adjudication

$3619 \quad$ Chief of Staff

3618 Special Assistant for Veterans Service Organization Liaison

3603 General Counsel

3604 Inspector General

3610 Board of Veterans Appeals

3612 Board of Contract Appeals

3613 Office of Small and Disadvantaged Business Utilization

3620 Under Secretary for Health / Veterans Health Administration

3630 Under Secretary for Memorial Affairs/National Cemetery System

3640 Under Secretary for Benefits / Veterans Benefit Administration

3605 Assistant Secretary for Management

3628 Immediate Office of Assistant Secretary for Management

3625 Deputy Assistant Secretary for Budget

3627 Deputy Assistant Secretary for Financial Management

3643 Deputy Assistant Secretary for Acquisition and Materiel Management

3644 Director - Asset Enterprise Management

3606 Assistant Secretary for Policy and Planning

3624

3622

3623

3655

3656

Immediate Office of Assistance Secretary for Policy and Planning

Deputy Assistant Secretary for Policy

Deputy Assistant Secretary for Planning and Evaluation

Deputy Assistant Secretary for Security Preparedness

3607 Assistant Secretary for Public and Intergovernmental Affairs

3636 Immediate Office of Assistance Secretary for Public and Intergovernmental Affairs 


\section{TABLE OF ORGANIZATIONS AND CODES EXECUTIVE DEPARTMENTS (and their associated organizations)}

\section{Code Organization}

3600 VETERANS AFFAIRS, Department of - continued

3637 Deputy Assistant Secretary for Intergovernmental Affairs and International Affairs

3638 Deputy Assistant Secretary for Public Affairs

3608 Assistant Secretary for Congressional and Legislative Affairs

$3646 \quad$ Immediate Office of Assistant Secretary for Congressional Affairs

3647 Director, Congressional Affairs

3648 Deputy Assistant Secretary for Legislative Affairs

3611 Assistant Secretary for Human Resources and Administration

3649

Immediate Office of Assistant Secretary for Human Resources and Administration

3632

3633

Deputy Assistant Secretary for Diversity and Equal Employment Opportunity

3634 Director - Office of Administration

3641 Deputy Assistant Secretary for Office of Resolution Management

3645 Associate Deputy for Labor - Management Relations

3650 Assistant Secretary for Information and Technology

3651 Immediate Office of the Assist. Sec. for Information \& Technology

3652 Deputy Assistant Sec. For Information \& Technology

3621 Director, Austin Automation Center 


\section{TABLE OF ORGANIZATIONS AND CODES EXECUTIVE DEPARTMENTS (and their associated organizations)}

\section{Code Organization}

9530 Advisory Council On Historic Preservation

1141 African Development Foundation

7200 U.S. Agency for International Development

7400 American Battle Monuments Commission

4602 Appalachian Regional Commission

9532 Architectural and Transportation Barriers Compliance Board

4965 Arctic Research Commission

84AF Armed Forces Retirement Home

97NH United States Naval Home

$8400 \quad$ United States Soldiers' and Airmen's Home

9560 Barry Goldwater Scholarship and Excellence in Education Foundation

9563 Financial Crisis Inquiry Commission

9568 Broadcasting Board of Governors

9522 Centennial of Flight Commission

5600 Central Intelligence Agency

9565 Chemical Safety and Hazard Investigation Board

7635 Christopher Columbus Fellowship Foundation

9567 Commission for the Preservation of America's Heritage Abroad

9537 Commission of Fine Arts

9517 Commission on Civil Rights 


\section{TABLE OF ORGANIZATIONS AND CODES OTHER INDEPENDENT FEDERAL AGENCIES, BOARDS, COMMISSIONS, COUNCILS, FOUNDATIONS, OFFICES, QUASI-FEDERAL ORGANIZATIONS AND \\ FEDERAL-STATE ORGANIZATIONS (and their associated organizations)}

\section{Code Organization}

4836 Commission on Executive, Legislative and Judicial Salaries

9518 Committee for Purchase from People who are Blind or Severely Disabled

9520 Privacy and Civil Liberties Oversight Board

9521 Commission to Eliminate Child Abuse and Neglect Fatalities

9526 Gulf Coast Ecosystem Restoration Council

9507 Commodity Futures Trading Commission

6100 Consumer Product Safety Commission

9577 Corporation for National and Community Service

2092 Corporation for Public Broadcasting

9594 Court Services and Offender Supervision Agency for the District of Columbia

959D Office of the Director - CSOSA

955P Pretrial Services Agency - CSOSA

9516 Defense Nuclear Facilities Safety Board

9547 Delta Regional Authority

9572 Denali Commission

9523 Election Assistance Commission 


\section{TABLE OF ORGANIZATIONS AND CODES OTHER INDEPENDENT FEDERAL AGENCIES, BOARDS, COMMISSIONS, COUNCILS, FOUNDATIONS, OFFICES, QUASI-FEDERAL ORGANIZATIONS AND \\ FEDERAL-STATE ORGANIZATIONS (and their associated organizations)}

\section{Code Organization}

6800 ENVIRONMENTAL PROTECTION AGENCY

680S Office of the Administrator of EPA

6801 Immediate Office of the Administrator of EPA

6802 Deputy Administrator

68SA Associate Administrator for Office of Public Affairs

68SB Associate Administrator for Congressional and Intergovernmental Relations

68SC Office of Homeland Security

68SD Environmental Appeals Board

68SE Executive Secretariat

68SF Office of Executive Services

68SG Office of Administrative Law Judges

$68 \mathrm{SH} \quad$ Office of Civil Rights

68SJ Office of Cooperative Environmental Management

68SK Office of Small and Disadvantaged Business Utilization

68SL Office of Policy, Economics and Innovation

68SM Science Advisory Board

68SN Office of Environmental Education

68SO Office of Children's Health Protection

6803 Office of General Counsel

6804 Office of the Inspector General

6805 Assistant Administrator for Administration and Resources Management

6809 Assistant Administrator for International Affairs

6820 Assistant Administrator for Air and Radiation

6825 Assistant Administrator for Enforcement and Compliance Assurance

6830 Assistant Administrator for Prevention, Pesticides, and Toxic Substances

6840 Assistant Administrator for Research and Development

6845 Assistant Administrator for Water

6850 Assistant Administrator for Solid Waste and Emergency Response

6860 Assistant Administrator for Environmental Information

6853 Office of the Chief Financial Officer 


\title{
TABLE OF ORGANIZATIONS AND CODES OTHER INDEPENDENT FEDERAL AGENCIES, BOARDS, COMMISSIONS, COUNCILS, FOUNDATIONS, OFFICES, QUASI-FEDERAL ORGANIZATIONS AND \\ FEDERAL-STATE ORGANIZATIONS (and their associated organizations)
}

\section{Code Organization}

\author{
Associated Federal Organization: \\ 4500 Equal Employment Opportunity Commission \\ 4567 Interagency Committee on Employment of People with Disabilities \\ 8300 Export-Import Bank of the U.S. \\ 7800 Farm Credit Administration \\ Government-Sponsored Enterprises: \\ $7881 \quad$ Bank for Cooperatives \\ $7884 \quad$ Farm Credit Banks \\ $7886 \quad$ Farm Credit System Financial Assistance Corporation \\ 7888 Farm Credit System Insurance Corporation \\ 7889 Federal Agricultural Mortgage Corporation (Farmer Mac) \\ 2700 Federal Communications Commission \\ 5100 Federal Deposit Insurance Corporation \\ 9506 Federal Election Commission
}




\section{TABLE OF ORGANIZATIONS AND CODES OTHER INDEPENDENT FEDERAL AGENCIES, BOARDS, COMMISSIONS, COUNCILS, FOUNDATIONS, OFFICES, QUASI-FEDERAL ORGANIZATIONS AND \\ FEDERAL-STATE ORGANIZATIONS (and their associated organizations)}

\section{Code Organization}

9562 Federal Financial Institutions Examination Council

9540 Federal Housing Finance Agency

Government-Sponsored Enterprise

95HL Federal Home Loan Banks

9585 Financing Corporation (FICO)

5400 Federal Labor Relations Authority

6500 Federal Maritime Commission

9300 Federal Mediation and Conciliation Service

9504 Federal Mine Safety and Health Review Commission

9559 Federal Reserve System, Board of Governors

2600 Federal Retirement Thrift Investment Board

2900 Federal Trade Commission 


\section{TABLE OF ORGANIZATIONS AND CODES OTHER INDEPENDENT FEDERAL AGENCIES, BOARDS, COMMISSIONS, COUNCILS, FOUNDATIONS, OFFICES, QUASI-FEDERAL ORGANIZATIONS AND \\ FEDERAL-STATE ORGANIZATIONS (and their associated organizations)}

\section{Code Organization}

$\begin{array}{ll}4700 & \text { GENERAL SERVICES ADMINISTRATION } \\ 4701 & \text { Immediate Office of the Administrator } \\ 4704 & \text { Office of Inspector General } \\ 4712 & \text { GSA Board of Contract Appeals } \\ 4703 & \text { Office of General Counsel } \\ 4705 & \text { Office of the Chief People Officer } \\ 4707 & \text { Office of Congressional and Intergovernmental Affairs } \\ 4708 & \text { Office of Citizen Services and Communications } \\ 4717 & \text { Office of the Chief Financial Officer } \\ 4722 & \text { Offices of the Regional Administrators } \\ 4724 & \text { Office of Civil Rights } \\ 4728 & \text { Office of Small Business Utilization } \\ 4732 & \text { Office of the Federal Acquisition Service } \\ 4740 & \text { Public Buildings Service } \\ 4745 & \text { Office of Governmentwide Policy } \\ 4750 & \text { Office of the Chief Information Officer } \\ 4743 & \text { Office of Childcare } \\ 4760 & \text { Office of the Chief Acquisition Officer }\end{array}$




\section{TABLE OF ORGANIZATIONS AND CODES OTHER INDEPENDENT FEDERAL AGENCIES, BOARDS, COMMISSIONS, COUNCILS, FOUNDATIONS, OFFICES, QUASI-FEDERAL ORGANIZATIONS AND FEDERAL-STATE ORGANIZATIONS (and their associated organizations)}

\section{Code Organization}

9510 Harry S. Truman Scholarship Foundation

9535 Institute of American Indian and Alaska Native Culture and Arts Development

9554 Interagency Council on the Homeless

1143 Inter-American Foundation

4607 Interstate Commission on the Potomac River Basin

9541 James Madison Memorial Fellowship Foundation

9542 Office of the Inspector General of the Federal Housing Finance Agency

9512 Japan-U.S. Friendship Commission

2095 Legal Services Corporation

9513 Marine Mammal Commission

4100 Merit Systems Protection Board

9543 Millennium Challenge Corporation

9545 Morris K. Udall Scholarship and Excellence in National Environmental Policy Foundation 


\title{
TABLE OF ORGANIZATIONS AND CODES OTHER INDEPENDENT FEDERAL AGENCIES, BOARDS, COMMISSIONS, COUNCILS, FOUNDATIONS, OFFICES, QUASI-FEDERAL ORGANIZATIONS AND \\ FEDERAL-STATE ORGANIZATIONS (and their associated organizations)
}

\section{Code Organization}

\author{
8000 NATIONAL AERONAUTICS AND SPACE ADMINISTRATION \\ 8001 Headquarters, NASA \\ 8020 Ames Research Center \\ 8044 George C. Marshall Space Flight Center \\ 8026 Goddard Space Flight Center \\ 8035 John F. Kennedy Space Center \\ 8038 Langley Research Center \\ 8041 John H. Glenn Research Center at Lewis Field \\ 8032 Lyndon B. Johnson Space Center \\ 8047 John C. Stennis Space Center \\ 8025 NASA Shared Services Center \\ 8022 Dryden Flight Research Center \\ 8029 NASA Management Office, Jet Propulsion Laboratory
}




\section{TABLE OF ORGANIZATIONS AND CODES OTHER INDEPENDENT FEDERAL AGENCIES, BOARDS, COMMISSIONS, COUNCILS, FOUNDATIONS, OFFICES, QUASI-FEDERAL ORGANIZATIONS AND \\ FEDERAL-STATE ORGANIZATIONS (and their associated organizations)}

\section{Code Organization}

8800 NATIONAL ARCHIVES AND RECORDS ADMINISTRATION

Associated Federal Organizations:

8852 Information Security Oversight Office

8861 National Archives Trust Fund Board

8862 National Historical Publications and Records Commission

8865 Administrative Committee of the Federal Register

9502 National Capital Planning Commission

9527 National Commission on Libraries and Information Science

9528 Office of the Federal Coordinator Alaska Natural Gas Transportation Projects

9529 World War I Centennial Commission

9555 National Communications System

9558 Consumer Financial Protection Bureau

9509 National Council on Disability

9525 National Counterintelligence Center

2500 National Credit Union Administration 


\section{TABLE OF ORGANIZATIONS AND CODES OTHER INDEPENDENT FEDERAL AGENCIES, BOARDS, COMMISSIONS, COUNCILS, FOUNDATIONS, OFFICES, QUASI-FEDERAL ORGANIZATIONS AND \\ FEDERAL-STATE ORGANIZATIONS \\ (and their associated organizations)}

\section{Code Organization}

\section{NATIONAL FOUNDATION ON THE ARTS AND THE HUMANITIES}

5915 Federal Council on the Arts and the Humanities

5950 Institute of Museum Services

5920 National Endowment for the Arts

5940 National Endowment for the Humanities

Associated Federal Organizations:

5963 National Council on the Arts

5966 National Council on the Humanities

6300 National Labor Relations Board

9524 National Mediation Board 


\section{TABLE OF ORGANIZATIONS AND CODES OTHER INDEPENDENT FEDERAL AGENCIES, BOARDS, COMMISSIONS, COUNCILS, FOUNDATIONS, OFFICES, QUASI-FEDERAL ORGANIZATIONS AND \\ FEDERAL-STATE ORGANIZATIONS \\ (and their associated organizations)}

\section{Code Organization}

4900 NATIONAL SCIENCE FOUNDATION

Associated Federal Organization:

4960 National Science Board

9508 National Transportation Safety Board

8291 Neighborhood Reinvestment Corporation

3100 Nuclear Regulatory Commission

4856 Nuclear Waste Technical Review Board

9514 Occupational Safety and Health Review Commission

9549 Office of Government Ethics

4849 Office of Navajo and Hopi Indian Relocation 


\section{TABLE OF ORGANIZATIONS AND CODES OTHER INDEPENDENT FEDERAL AGENCIES, BOARDS, COMMISSIONS, COUNCILS, FOUNDATIONS, OFFICES, QUASI-FEDERAL ORGANIZATIONS AND \\ FEDERAL-STATE ORGANIZATIONS (and their associated organizations)}

\section{Code Organization}

2400 OFFICE OF PERSONNEL MANAGEMENT

2401 Office of the Director

2402 Office of the General Counsel

2403 Office of Communications and Public Liaison

2404 Office of Congressional Relations

2405 Office of Inspector General

2406 Office of the Chief Financial Officer

2407 Division of Human Capital Leadership and Merit System Accountability

2408 Division for Strategic Human Resource Policy

2409 Federal Investigative Service Division

2410 Management Services Division

2411 Human Resources Line of Business Office

2412 Federal Prevailing Rate Advisory Committee

2413 Chief Human Capital Leadership and Merit System Accountability

2414 Other Division or Office Designations

2415 Federal Executive Board or Federal Executive Association

Associated Federal Organizations:

2460 Federal Prevailing Rate Advisory Committee

2461 President's Commission on White House Fellowships

Federal Executive Boards (FEB)

24P1 Federal Executive Board-Albuquerque, NM

24P4 Federal Executive Board-Atlanta, GA

24P7 Federal Executive Board-Baltimore, MD

24Q1 Federal Executive Board-Boston, MA

24Q4 Federal Executive Board-Buffalo, NY

24Q7 Federal Executive Board-Chicago, IL

24R1 Federal Executive Board-Cincinnati, $\mathrm{OH}$

24R4 Federal Executive Board-Cleveland, $\mathrm{OH}$

24R7 Federal Executive Board-Dallas-Ft.Worth, TX

24S1 Federal Executive Board-Denver, CO

24S4 Federal Executive Board-Detroit, MI

24S7 Federal Executive Board-Honolulu, HI 


\section{TABLE OF ORGANIZATIONS AND CODES OTHER INDEPENDENT FEDERAL AGENCIES, BOARDS, COMMISSIONS, COUNCILS, FOUNDATIONS, OFFICES, QUASI-FEDERAL ORGANIZATIONS AND \\ FEDERAL-STATE ORGANIZATIONS (and their associated organizations)}

\section{Code Organization}

24T1 Federal Executive Board-Houston, TX 24T4 Federal Executive Board-Kansas City, KS

24T7 Federal Executive Board-Los Angeles, CA

24V1 Federal Executive Board-Miami, FL

24V4 Federal Executive Board-Newark, NJ

24V7 Federal Executive Board-New Orleans, LA

24W1 Federal Executive Board-New York City, NY

24W4 Federal Executive Board-Oklahoma, City, OK

24W7 Federal Executive Board-Philadelphia, PA

24X1 Federal Executive Board-Pittsburgh, PA

24X4 Federal Executive Board-Portland, OR

24X7 Federal Executive Board-St. Louis, MO

24Y1 Federal Executive Board-San Antonio, TX

24Y4 Federal Executive Board-San Francisco, CA

24Y7 Federal Executive Board-Seattle, WA

$24 \mathrm{Z} 1$ Federal Executive Board-Twin Cities, MN 


\section{TABLE OF ORGANIZATIONS AND CODES OTHER INDEPENDENT FEDERAL AGENCIES, BOARDS, COMMISSIONS, COUNCILS, FOUNDATIONS, OFFICES, QUASI-FEDERAL ORGANIZATIONS AND \\ FEDERAL-STATE ORGANIZATIONS (and their associated organizations)}

\section{Code Organization}

6201 Office of Special Counsel

7100 Overseas Private Investment Corporation

1145 Peace Corps

9570 Presidio Trust

6000 Railroad Retirement Board

5000 Securities and Exchange Commission

Federally Aided Organization:

5094 Securities Investor Protection Corporation

9000 Selective Service System

7300 Small Business Administration

Associated Federal Organization

7360 National Women's Business Council

3300 Smithsonian Institution, except units administered under separate Board of Trustees

3320 Smithsonian Institution, except units administered under separate Boards of Trustees

3352 John F. Kennedy Center for the Performing Arts

3355 National Gallery of Art

3358 Woodrow Wilson International Center for Scholars 


\section{TABLE OF ORGANIZATIONS AND CODES OTHER INDEPENDENT FEDERAL AGENCIES, BOARDS, COMMISSIONS, COUNCILS, FOUNDATIONS, OFFICES, QUASI-FEDERAL ORGANIZATIONS AND \\ FEDERAL-STATE ORGANIZATIONS (and their associated organizations)}

\section{Code Organization}

2800

2801

2803

2804

2814

2805

2806

2807

2810

2811

2812

2816

2818

4817 State Justice Institute

6400 Tennessee Valley Authority

Government Sponsored Enterprise

2281 Resolution Funding Corporation (REFCORP)

1153 Trade and Development Agency

NOTE: This agency was previously a part of the International Development Cooperation Agency. The code has not been changed.

9589 United Mine Workers of America Benefit Funds

9531 United States Holocaust Memorial Museum 


\section{TABLE OF ORGANIZATIONS AND CODES OTHER INDEPENDENT FEDERAL AGENCIES, BOARDS, COMMISSIONS, COUNCILS, FOUNDATIONS, OFFICES, QUASI-FEDERAL ORGANIZATIONS AND \\ FEDERAL-STATE ORGANIZATIONS (and their associated organizations)}

\section{Code Organization}

Associated Federal Organizations:

9580 United States Institute of Peace

3400 U.S. International Trade Commission

7200 Agency for International Development

7100 Overseas Private Investment Corporation

1800 U. S. Postal Service

1804 Office of the Inspector General of the U.S. Postal Service

1810 U. S. Postal Inspection Service

Associated Federal Organization:

1861 Postal Regulatory Commission

1865 Citizens' Stamp Advisory Committee

9590 Valles Caldera Trust

9591 Vietnam Education Foundation

9574 White House Commission on the National Moment of Remembrance

4608 The Port Authority of NY and NJ

4609 Washington Metropolitan Area Transit Authority 


\section{TABLE OF ORGANIZATIONS AND CODES OTHER INDEPENDENT FEDERAL AGENCIES, BOARDS, COMMISSIONS, COUNCILS, FOUNDATIONS, OFFICES, QUASI-FEDERAL ORGANIZATIONS AND FEDERAL-STATE ORGANIZATIONS (and their associated organizations)}

\section{Code Organization}

\section{INTER-AMERICAN ORGANIZATIONS}

19AN Inter-American Indian Institute

19AA Inter-American Institute for Cooperation on Agriculture

19AS Organization of American States

19AH Pan-American Health Organization

19AG Pan-American Institute of Geography and History

19AR Pan-American Railway Congress Association

18AP Postal Union of the Americas and Spain and Portugal

\section{INTERNATIONAL BOUNDARY COMMISSIONS}

19BM International Boundary and Water Commission: U.S.-Mexico

19BC International Boundary Commission: U.S. and Canada

19BJ International Joint Commission: U.S. and Canada

19BE U.S. - Canada Border Environment Cooperation Commission

\section{BILATERAL ORGANIZATIONS}

19DM Joint Mexican-United States Defense Commission

19DC Permanent Joint Board on Defense - U.S. \& Canada

\section{INTERNATIONAL FISHERIES ORGANIZATIONS}

19FR Commission for the Conservation of Antarctic Marine Living Resources

19FG Great Lakes Fishery Commission

19FT Inter-American Tropical Tuna Commission

19FL International Commission for the Conservation of Atlantic Tunas

19FE International Council for the Exploration of the Sea

19FD Pacific Salmon Commission

19FY North Pacific Marine Science Organization

19FK North Pacific Anadromous Fish Commission

19FH International Pacific Halibut Commission

19FW International Whaling Commission

19FA North Atlantic Salmon Conservation Organization

19FN Northwest Atlantic Fisheries Organization 


\section{TABLE OF ORGANIZATIONS AND CODES OTHER INDEPENDENT FEDERAL AGENCIES, BOARDS, COMMISSIONS, COUNCILS, FOUNDATIONS, OFFICES, QUASI-FEDERAL ORGANIZATIONS AND \\ FEDERAL-STATE ORGANIZATIONS (and their associated organizations)}

\section{Code Organization}

\section{MEMORIAL, MIGRATION AND REFUGEE AID ORGANIZATIONS}

19ME International Organization for Migration

19MR International Committee of the Red Cross

19MC U.N. Memorial Cemetery Commission

\section{MULTILATERAL DEVELOPMENT BANKS}

11DB African Development Fund

11DE Asian Development Bank

11DK European Bank for Reconstruction and Development

11DT Inter-American Defense Board

11DH Inter-American Development Bank

11DR International Bank for Reconstruction and Development (World Bank)

11DA International Development Association

11DF International Finance Corporation

11DG International Fund for Agricultural Development

11DM International Monetary Fund

11DW Multilateral Investment Guarantee Agency

11DN North American Development Bank

\section{REGIONAL ORGANIZATIONS}

19RJ Asia-Pacific Economic Cooperation

19RC Colombo Plan Council for Technical Cooperation

19RD Colombo Plan for Cooperative Economic and Social

Development in Asia and the Pacific

11RF Multinational Force and Observers

19RA North Atlantic Assembly

19RN North Atlantic Treaty Organization

19RE Organization for Economic Cooperation and Development

19RP South Pacific Commission 


\section{TABLE OF ORGANIZATIONS AND CODES OTHER INDEPENDENT FEDERAL AGENCIES, BOARDS, COMMISSIONS, COUNCILS, FOUNDATIONS, OFFICES, QUASI-FEDERAL ORGANIZATIONS AND \\ FEDERAL-STATE ORGANIZATIONS (and their associated organizations)}

\section{Code Organization}

\section{UNITED NATIONS AND AFFILIATED AGENCIES}

19UF Food and Agriculture Organization

19UE International Atomic Energy Agency

19UA International Civil Aviation Organization

19UL International Labor Organization

19UG International Maritime Organization

19UT International Telecommunication Union

19UN United Nations (and special programs)

19UK United Nations Industrial Development Organization

19UP Universal Postal Union

19UH World Health Organization

19UW World Intellectual Property Organization

19UM World Meteorological Organization 


\section{TABLE OF ORGANIZATIONS AND CODES OTHER INDEPENDENT FEDERAL AGENCIES, BOARDS, COMMISSIONS, COUNCILS, FOUNDATIONS, OFFICES, QUASI-FEDERAL ORGANIZATIONS AND \\ FEDERAL-STATE ORGANIZATIONS \\ (and their associated organizations)}

\section{Code Organization}

WORLD ORGANIZATIONS, Other

Commodity-Oriented

19CF International Coffee Organization

19CU International Copper Study Group

19CC International Cotton Advisory Committee

12CN International Institute for Cotton

19CJ International Jute Organization

19CL International Lead and Zinc Study Group

19CB International Natural Rubber Organization

19CV International Office of the Vine and Wine

19CR International Rubber Study Group

19CS International Sugar Organization

19CX International Tropical Timber Organization

19CW International Wheat Council

Experimentation, Measurement, Research, and Study

19EC International Agency for Research on Cancer

19EM International Bureau of Weights and Measures

19EP International Center for the Study of the Preservation and

Restoration of Cultural Property

19EZ International Office of Epizootics

19ES International Seed Testing Association

$19 E V$ International Union for the Protection of New Varieties of Plants

$\underline{\text { Interparliamentary Organizations }}$

19PC Canada-United States Interparliamentary Group

19PU Interparliamentary Union

19PM Mexico-United States Interparliamentary Group 


\title{
TABLE OF ORGANIZATIONS AND CODES OTHER INDEPENDENT FEDERAL AGENCIES, BOARDS, COMMISSIONS, COUNCILS, FOUNDATIONS, OFFICES, QUASI-FEDERAL ORGANIZATIONS AND \\ FEDERAL-STATE ORGANIZATIONS (and their associated organizations)
}

\section{Code Organization}

\author{
$\underline{\text { Law-Oriented }}$ \\ 19LH Hague Conference on Private International Law \\ 19LA International Bureau of the Permanent Court of Arbitration \\ 20LP International Criminal Police Organization (INTERPOL) \\ 19LU International Institute for the Unification of Private Law \\ 19LM International Organization for Legal Metrology
}

Navigation, Travel Safety

19NH International Hydrographic Organization

96NC Permanent International Association of Navigation Congresses

96RC Permanent International Association of Road Congresses 


\section{WORLD ORGANIZATIONS, Other - Continued}

$\underline{\text { Scientific Unions and Councils }}$

49SZ Committee on Science and Technology for Development

49SO International Commission on Optics

49SU International Council of Scientific Unions

49SA International Astronomical Union

49SG International Geographical Union

49SE International Geological Union

49SM International Mathematical Union

49SV International Union for Pure and Applied Biophysics

49SQ International Union for Quaternary Research

49SK International Union of Biochemistry \& Molecular Biology

49SB International Union of Biological Sciences

49SX International Union of Crystallography

49SD International Union of Geodesy and Geophysics

49SW International Union of Microbiological Societies

49SN International Union of Nutritional Sciences

49SP International Union of Physiological Sciences

49SS International Union of Psychological Science

49SC International Union of Pure and Applied Chemistry

49SF International Union of Pure and Applied Physics

49SR International Union of Radio Sciences

49ST International Union of Theoretical and Applied Mechanics

49SY Pacific Science Association

$\underline{\text { Tariffs, Tourism, and Trade }}$

19TX Bureau of International Expositions

19TC Customs Cooperation Council

19TT General Agreement on Tariffs and Trade

19TP International Bureau for the Publication of Customs Tariffs

19TW World Tourism Organization 
Table of Organizations and Codes

Part B: Arrangement by Alphanumeric Sequence of Assigned Codes 


\section{THE LEGISLATIVE BRANCH}

0001 Congress, generally, no additional specification available

0010 Senate, The

0050 House of Representatives, The

0099 Joint House and Senate Entities

0100 Architect of the Capitol

0300 Library of Congress

0361 Library of Congress Trust Fund Board

0363 Federal Library \& Information Center Committee

0400 Government Printing Office

0500 Government Accountability Office

$0501 \quad$ Comptroller General of the United States

0559 GAO, except Comptroller General

0800 Congressional Budget Office

0901 Commission on Security and Cooperation in Europe

0902 Botanic Garden

0904 Office of Compliance

0905 Dwight D. Eisenhower Memorial Commission

0914 John C. Stennis Center for Public Service Training and Development

0915 Advisory Commission on Electronic Commerce

0916 National Commission on Terrorism

0923 Commission on the People's Republic of China

0929 U.S. Capitol Preservation Commission

0938 Abraham Lincoln Bicentennial Commission

0962 Permanent Committee for the Oliver Wendell Holmes Devise

0973 National Commission on Terrorist Attacks upon the United States

0975 Commission on the Review of the Overseas Military Facility Structure of the United States

0977 Antitrust Modernization Commission

1000 THE JUDICIAL BRANCH

1001 Supreme Court of the United States

1002 U.S. Courts of Appeals-Judicial Circuits - except the Federal Circuit

1003 U.S. Court of Appeals for the Federal Circuit

1004 U.S. Court of International Trade

1005 U.S. Court of Federal Claims

1012 U.S. District and Territorial Courts

1018 U.S. Judicial Panel on Multidistrict Litigation

1021 Bankruptcy Courts

1023 Federal Public Defenders

1025 Court Security

1027 Administrative Office of the U.S. Courts

1028 Federal Judicial Center

1030 United States Sentencing Commission

1050 Chief Justice of the United States 
1051 Associate Justices of the Supreme Court

1059 Supreme Court, except Justices

1060 Judicial Conference of the United States

1100 EXECUTIVE OFFICE OF THE PRESIDENT

1101 President of the United States

1102 National Security Council

1103 Office of Management and Budget

1105 Office of Administration

1109 Office of the United States Trade Representative

1110 Office of Policy Development

1112 Office of Science and Technology Policy

1113 Council of Economic Advisors

1117 White House Office

1118 Executive Residence at the White House

1119 Council on Environmental Quality/Office of Environmental Quality

1121 Director, OMB

1127 Office of the National Drug Control Policy

1129 OMB, except Director

1140 President's Council on Sustainable Development

1141 African Development Foundation

1143 Inter-American Foundation

1145 Peace Corps

1148 Office of Homeland Security

1153 Trade and Development Agency

1160 Office of the Vice President of the United States

1165 White House Commission on Presidential Scholars

1170 Commission on the Intelligence Capabilities of the United States Regarding Weapons of Mass Destruction

11DA International Development Association

11DB African Development Fund

11DE Asian Development Bank

11DF International Finance Corporation

11DG International Fund for Agricultural Development

11DH Inter-American Development Bank

11DK European Bank for Reconstruction and Development

11DM International Monetary Fund

11DN North American Development Bank

11DR International Bank for Reconstruction and Development (World Bank)

11DT Inter-American Defense Board

11DW Multilateral Investment Guarantee Agency

11RF Multinational Force and Observers 
1200 AGRICULTURE, Department of

1201 Office of the Secretary of Agriculture

1203 USDA, Office of the General Counsel

1204 Office of the Inspector General

1205 USDA, Office of the Chief Financial Officer

1208 USDA, Office of Communications

1215 USDA, Office of Operations

1260

1261

1263

1291

$12 \mathrm{~A} 0$

12A2

$12 \mathrm{~A} 4$

$12 \mathrm{~A} 5$

$12 \mathrm{~A} 6$

12A7

12A8

$12 \mathrm{~A} 9$

\section{Commodity Credit Corporation}

Rural Telephone Bank Federal Crop Insurance Corporation

Land grant colleges and Tuskegee Institute

USDA, Office of Executive Operations

USDA, Office of Executive Secretariat

USDA, Homeland Security

USDA, Office of the Chief Economist

USDA, Office of Budget and Program Analysis

USDA, Office of the Chief Information Officer

USDA, Office of Small and Disadvantaged Business USDA, National Appeals Division

USDA, Assistant Secretary for Administration

USDA, Office of Security Services

USDA, Civil Rights

Property and Procurement Management

USDA, Office of Human Capital Management

USDA, Office of the Administrative Law Judge

USDA, Office of the Judicial Officer

USDA, Board of Contract Appeals

USDA, Office of Ethics

Under Secretary for Natural Resources and Environment

Forest Service

Natural Resources Conservation Service

International Institute for Cotton

Under Secretary for Farm and Foreign Agricultural Services

Farm Service Agency

Foreign Agricultural Service

Risk Management Agency

Under Secretary for Rural Development

Rural Utilities Service

Rural Housing Service

Rural Business Cooperative Service

12F0 Under Secretary for Food, Nutrition, and Consumer Services

12F2 Food and Nutrition Service

$12 \mathrm{~F} 3$

Center for Nutrition Policy and Promotion 
12G0 Under Secretary for Food Safety

12G2 Food Safety and Inspection Service

12H0 Under Secretary for Research, Education, and Economics

12H2 Agricultural Research Service

12H3 Cooperative State Research, Education, and Extension Service

12H4 Economic Research Service

12H5 National Agricultural Statistics Service

$12 \mathrm{~J} 0$

$12 \mathrm{~J} 2$

Assistant Secretary for Congressional Relations

12K0 Under Secretary for Marketing and Regulatory Programs

$12 \mathrm{~K} 2$

$12 \mathrm{~K} 3$

Agricultural Marketing Service

$12 \mathrm{~K} 4$

Animal and Plant Health Inspection Service

Grain Inspection, Packers and Stockyards Administration

1300 COMMERCE, Department of

1301 Office of the Secretary

$1303 \quad$ Office of the General Counsel

1304 Office of the Inspector General

$1306 \quad$ Office - Chief Financial Officer \& Assist. Sec’y for Admin.

1314 Economic and Statistics Administration/Under Secretary for Economic Affairs

$1315 \quad$ Chief Economist

1321 Bureau of Economic Analysis

1323 Bureau of the Census

1325 Economic Development Administration/Assistant Secretary for Economic Development

1330 National Oceanic and Atmospheric Administration/Under Secretary for Oceans and Atmosphere

1335 National Telecommunication and Information Administration/Assistant Secretary for Communications and Information

1341 National Institute of Standards and Technology

1342 National Technical Information Service

1343 Assistant Secretary for Technology Policy

1344 Patent and Trademark Office/Under Secretary for Intellectual Property

1350 International Trade Administration

1351 Under Secretary for Export Administration/Bureau of Industry and Security

1352 Minority Business Development Agency

1359 Technology Administration/Under Secretary of Technology

1363 Committee for the Implementation of Textile Agreements

1365 Export Administration Review Board

1400 INTERIOR, Department of the

1401 Office of the Secretary of the Interior

1402 Office of the Deputy Secretary of the Interior

1403 Office of the Solicitor

1404 Office of the Inspector General 
1406

1506 Environment and Natural Resources Division

1507 Foreign Claims Settlement Commission

1508 Justice Management Division

1509 Office of the Assistant Attorney General

1510 Office of the Attorney General

1511 Office of the Deputy Attorney General

Office of Congressional and Legislative Affairs

Office of Communications

Office of Insular Affairs

Office of The Chief Information Officer

Office for Equal Opportunity

Office of Hearings and Appeals

Office of Historic Trust Accounting

Bureau of Land Management

Bureau of Reclamation

National Business Center

Fish and Wildlife and Parks (Assistant Secretary)

Land and Minerals Management (Assistant Secretary)

Geological Survey

Bureau of Ocean Energy Management

National Park Service.

U.S. Fish and Wildlife Service

Indian Affairs (Assistant Secretary)

Board on Geographic Names

Migratory Bird Conservation Commission

Metropolitan River Corridors Study Committee

Endangered Species Committee

Indian Arts and Crafts Board

National Indian Gaming Commission

JUSTICE, Department of

Offices, Boards and Divisions

Division

Criminal Division

Office of the Inspector General

Civil Rights Division

Office of Policy, Management and Budget/Chief Financial Officer

Executive Secretariat \& Office of Regulatory Affairs

Office of the Special Trustee for American Indians

Bureau of Safety and Environmental Enforcement

Office of Surface Mining, Reclamation and Enforcement

Illinois and Michigan Canal National Heritage Corridor Commission

Utah Reclamation Mitigation and Conservation Commission 
1512 Office of Information Policy

1513 Office of Legislative Affairs

1514 Office of Legal Counsel

1515 Office of the Pardon Attorney

1516 Office of Professional Responsibility

1517 Office of the Solicitor General

1518 Office of Public Affairs

1519 Tax Division

1920 United States National Central Bureau

1921 United States Parole Commission

1522 Community Oriented Policing Services

1523 National Drug Intelligence Center

1524 Drug Enforcement Administration

1525 National Security Division

1526 Executive Office for U.S. Attorneys and the Offices of U.S. Attorneys

1527 Office of Dispute Resolution

1528 Immigration and Naturalization Service

1529 Office of Intergovernmental and Public Liaison

1530 Executive Office for Immigration Review

1531 Office of Legal Policy

1532 Office on Violence Against Women

1533 Professional Responsibility Advisory Office

1535 Community Relations Service

1536 Antitrust Division

1537 Office of the Federal Detention Trustee

1538 Office of Privacy and Civil Liberties

1540 Bureau of Prisoners/Federal Prison System

1544 U.S. Marshals Service

1549 Federal Bureau of Investigation

1550 Office of Justice Programs

1555 Executive Office for U.S. Trustees

1560 Bureau of Alcohol, Tobacco, Firearms and Explosives

1600 LABOR, Department of

1601 Immediate Office of the Secretary of Labor

1603 Office of the Solicitor

1604 Office of Inspector General

1605 Office of the Assistant Secretary for Administration and Management

1606 Office of the Assistant Secretary for Policy

1607 Office of the Assistant Secretary of Labor for Congressional and Intergovernmental Affairs

1608 Office of Public Affairs

1609 Bureau of International Labor Affairs

160 S Office of the Secretary of Labor

160U Office of the Deputy Secretary of Labor 
1610

1613

1615

1616

1617

1618

1631

1619

1620

1621

1622

1623

1625

1630

1635

1645

1650

1653

1655

1665

1667

1700

1708

1709

1710

1711

1712

1714

1715

1718

1719

1722

1723

1724

1725

1727

1730

1733

1739

1741

1752

1760

1761

Office of Adjudicatory Services

Office of Administrative Law Judges

Benefits Review Board

Employees Compensation Appeals Board

Administrative Review Board

Office of Small Business Programs

Office of Job Corps

Executive Secretariat

Office of $21^{\text {st }}$ Century Workforce

Employee Benefits Security Administration

Office of the Chief Financial Officer

Center for Faith-based and Community Initiatives

Bureau of Labor Statistics

Employment and Training Administration

Employment Standards Administration

Mine Safety and Health Administration

Occupational Safety and Health Administration

Veterans Employment and Training Services

Women's Bureau

Pension Benefit Guaranty Corporation

Office of Disability Employment Policy

NAVY, Department of the Immediate Office of the Secretary of the Navy Navy Staff Offices

Navy Field Offices

Immediate Office of the Chief of Naval Operations

Navy Secretariat/Staff Offices

Office of Naval Research

Naval Intelligence Command

Naval Medical Command

Naval Air Systems Command

Bureau of Naval Personnel

Naval Supply Systems Command

Naval Sea Systems Command

Naval Facilities Engineering Command

U.S. Marine Corps

Special Projects Office

Military Sealift Command

Naval Space and Warfare Systems Command

Naval Systems Management Activity

Commander, Navy Installations

U.S. Atlantic Fleet, Commander In Chief

U.S. Naval Forces, Europe 
1762

1763

1765

1769

1770

1772

1774

1776

$17 Z S$

1800

1804

1810

1861

1865

Postal Regulatory Commission

Citizens' Stamp Advisory Committee

18AP Postal Union of the Americas and Spain and Portugal

1900

1901

1902

1903

1904

1905

1906

1907

$190 \mathrm{~S}$

1910

1911

1912

1913

1914

1915

1916

1917

1918

1921

1923

1925

1927

1928

1929

1930

1931

1932

Chief of Naval Education and Training

Naval Network Operations Command

Naval Oceanography Command

Naval Security Group Command

U.S. Pacific Fleet, Commander in Chief

Naval Reserve Force

Naval Special Warfare Command

Naval Education and Training Command

U.S. Special Operations Command (Navy)

U.S. POSTAL SERVICE

Office -Inspector General of the U.S. Postal Service

U.S. Postal Inspection Service

STATE, Department of

Immediate Office of the Secretary of State

Office of the Deputy Secretary of State

Office of the Legal Adviser

Office of the Inspector General

Office of the Under Secretary for Management

Policy Planning Council

Bureau of Legislative Affairs

Office of the Secretary of State

Chief of Protocol

Office of Equal Employment Opportunity and Civil Rights

Coordinator for Counter-Terrorism

Office of the Under Secretary for Political Affairs

Office of the Under Secretary for Economic and Agricultural Affairs

Office of the Under Sec'y for Arms Control \& Internat'l Security Affairs

Counselor of the Department

Office of Executive Secretary

Chief of Staff

Bureau of African Affairs

Bureau of East Asian and Pacific Affairs

Bureau of European and Eurasian Affairs

Bureau of Western Hemisphere Affairs

Bureau of South Asian Affairs

Bureau of Near Eastern Affairs

Bureau of Consular Affairs

Chief Financial Officer

Foreign Service Institute 
1933

1935

1936

1937

1938

1939

1941

1942

1943

1945

1946

1948

1950

1951

1952

1953

1954

1955

1956

1957

1959

195A

1960

1961

1962

1963.

1964

1965

1966

1967

1968

1969

195B

195C

1958

1959

1991

1993

19AA Inter-American Institute for Cooperation on Agriculture

19AG Pan-American Institute of Geography and History

19AH Pan-American Health Organization

19AN Inter-American Indian Institute

19AR Pan-American Railway Congress Association

19AS Organization of American States

19BC

19BE

Bureau of Democracy, Human Rights and Labor

Bureau of Administration

Bureau of Intelligence and Research

Office of the Under Secretary for Global Affairs

Office of Information Resources Management

Bureau of International Organization Affairs

Bureau of Resource Management

Bureau of Political-Military Affairs

Assistant Secretary for Arms Control

Bureau of Public Affairs

Refugees and Migration

Office of International Information Programs

Artistic Ambassador Advi

Board of Foreign Scholarships

Cultural Property Advisory Committee

J. William Fulbright Foreign Scholarship Board

Eastern Europe Student Exchange Program

Russian Far East Technical Assistance Center

National Endowment for Democracy

Israeli Arab Scholarship Program

Broadcasting Board of Governors

Office of U.S. Ambassador to the United Nations

Office of International Information Programs

American Institute in Taiwan
Bureau of Economic and Business Affairs

Bureau of Diplomatic Security and Office of Foreign Missions

Bureau of International Narcotics and Law Enforcement Affairs

Bureau of Oceans \& Internat'l Environmental \& Scientific Affairs

Assistant Secretary for Verification and Compliance

International Public Information Core Group Secretariat

U.S. Advisory Commission on Public Diplomacy

Center for Cultural and Technical Interchange Between East and West

Center for Cultural and Technical Interchange Between North and South

U.S. and Canada International Boundary Commission

U.S. and Canada Border Environment Cooperation Commission 
19BJ U.S. and Canada International Joint Commission

19BM U.S. and Mexico International Boundary and Water Commission

19CB International Natural Rubber Organization

19CC International Cotton Advisory Committee

19CF International Coffee Organization

19CJ International Jute Organization

19CL International Lead and Zinc Study Group

19CR International Rubber Study Group

19CS International Sugar Organization

19CU International Copper Study Group

19CV International Office of the Vine and Wine

19CW International Wheat Council

19CX International Tropical Timber Organization

19DC Permanent Joint Board on Defense - U.S. \& Canada

19DM Joint Mexican-United States Defense Commission

19EC International Agency for Research on Cancer

19EM International Bureau of Weights and Measures

19EP Internat'l Cntr -- Study of the Preserv. \& Restoration of Cultural Property

19ES International Seed Testing Association

19EV International Union for the Protection of New Varieties of Plants

19EZ International Office of Epizootics

19FA North Atlantic Salmon Conservation Organization

19FD Pacific Salmon Commission

19FE International Council for the Exploration of the Sea

19FG Great Lakes Fishery Commission

19FH International Pacific Halibut Commission

19FK North Pacific Anadromous Fish Commission

19FL International Commission for the Conservation of Atlantic Tunas

19FN Northwest Atlantic Fisheries Organization

19FR Commission for the Conservation of Antarctic Marine Living Resources

19FT Inter-American Tropical Tuna Commission

19FW International Whaling Commission

19FY North Pacific Marine Science Organization

19LA International Bureau of the Permanent Court of Arbitration

19LH Hague Conference on Private International Law

19LM International Organization for Legal Metrology

19LU International Institute for the Unification of Private Law

19MC U.N. Memorial Cemetery Commission

19ME International Organization for Migration

19MR International Committee of the Red Cross

19NH International Hydrographic Organization

19PC Canada-United States Interparliamentary Group

19PM Mexico-United States Interparliamentary Group

19PU Interparliamentary Union

19RA North Atlantic Assembly

19RC Colombo Plan Council for Technical Cooperation 
19RD Colombo Plan for Coop. Econ. \& Social Develop. in Asia and the Pacific

19RE Organization for Economic Cooperation and Development

19RJ Asia-Pacific Economic Cooperation

19RN North Atlantic Treaty Organization

19RP South Pacific Commission

19TC Customs Cooperation Council

19TP International Bureau for the Publication of Customs Tariffs

19TT General Agreement on Tariffs and Trade

19TW World Tourism Organization

19TX Bureau of International Expositions

19UA International Civil Aviation Organization

19UE International Atomic Energy Agency

19UF Food and Agriculture Organization

19UG International Maritime Organization

19UH World Health Organization

19UK United Nations Industrial Development Organization

19UL International Labor Organization

19UM World Meteorological Organization

19UN United Nations (and special programs)

19UP Universal Postal Union

19UT International Telecommunication Union

19UW World Intellectual Property Organization

2000 TREASURY, Department of the

2001 Departmental Offices

2004 Inspector General

2014 Office of the Inspector General for Tax Administration

2022 Alcohol and Tobacco Tax and Trade Bureau

2026 Financial Crimes Enforcement Network

2041 Bureau of Engraving and Printing

2042 Bureau of the Fiscal Service

2044 United States Mint

2046 Office of the Comptroller of the Currency

2050 Internal Revenue Service

$2061 \quad$ Federal Financing Bank

2066 Community Development Financial Institutions

2092 Corporation for Public Broadcasting

2093 District of Columbia

2094 District of Columbia Public School

2095 Legal Services Corporation

20LP International Criminal Police Organization (INTERPOL) 
2100 ARMY, Dept. of the (except Corps of Engineers Civil program financing) National Guard Bureau Acquisition Executive Support Command Agency U.S. Army Intelligence and Security Command U.S. Army Test and Evaluation Command U.S. Army Audit Agency U.S. Army Installation Management Agency

U.S. Army Information Systems Command Immed. Office - Comm.-In-Chief - U.S. Army Europe $\& 7^{\text {th }}$ Army 21st Theater Army Area Command U.S. Army Southern European Task Force U.S. Army V Corps 1st Personnel Command U.S. Military Community Activity, Heidelberg Seventh Army Training Command 59th Ordnance Brigade

U.S. Army Forces Command

21G6

21GB

21HR

21HS

21J1

21JA

21MA

$21 \mathrm{MC}$

21MD

21MP

21MT

$21 \mathrm{MW}$

21NG

21P1

21P8

21PC

21RC

U.S. Army South Command

U.S. Army Network Enterprise Technology Command/9th Army Signal Command

21SA Office of the Secretary of the Army

21SB Field Operating Offices of the Office of the Secretary of the Army

21SC U.S. Army Space and Strategic Defense Command

21SE Field Operating Agencies of the Army Staff Resourced through OA-22

21SF Field Operating Agencies of the Army Staff

21SJ Joint Services \& Activities Supported by the Office, Sec'y of the Army

21SP U.S. Special Operation Command (Army) 
21SS Staff Support Agencies of the Chief of Staff, Army

21SU U.S. Army Southern Command

21TC U.S. Army Training and Doctrine Command

21X1 U.S. Army Materiel Command (AMC)

21X2

Headquarters, Army Materiel Command

21X3

Headquarters, Staff Support Activities, AMC

21X4

Training Activities, AMC

21X5

21X6

U.S. Army Materiel Command, all others

U.S. Army Missile Command

21X7

U.S. Army Tank-Auto. \& Armament Command (TACOM)

21X8

U.S. Army Communications Electronics Command

21X9

U.S.A. Simulation, Training \& Instrumentation Command

21XA

U.S. Army Chemical And Biological Defense Command

$21 \mathrm{XB}$

U.S. Army Chemical Materials Command

21XC

U.S. Army Soldiers System Command (SSC)

21XD

U.S. Army Research Laboratory Command

21XK

Materiel Acquisition Activities

21XL

21XP

Materiel Acquisition Project Managers

21XQ

U.S. Army Security Assistance Command

$21 \mathrm{XR}$

U.S. Army Operations Support Command

21XT

U.S. Army Research, Development and Engineering Command

$21 \mathrm{XX}$

U.S. Army Test, Measure, \& Diagnostic Equip. Activity

Materiel Readiness Activities

2281 Resolution Funding Corporation (REFCORP)

2300 U.S. Tax Court

2400 OFFICE OF PERSONNEL MANAGEMENT

2401 Office of the Director

2402 Office of the General Counsel

2403 Office of Communications and Public Liaison

2404 Office of Congressional Relations

2405 Office of Inspector General

2406 Office of the Chief Financial Officer

2407 Division of Human Capital Leadership and Merit System Accountability

2408 Division for Strategic Human Resource Policy

2409 Federal Investigative Service Division

2410 Management Services Division

2411 Human Resources Line of Business Office

2412 Federal Prevailing Rate Advisory Committee

2413 Chief Human Capital Leadership and Merit System Accountability

2414 Other Division or Office Designations

2415 Federal Executive Board or Federal Executive Association

2460 Federal Prevailing Rate Advisory Committee

2461 President's Commission on White House Fellowships 
24P1 Federal Executive Board-Albuquerque, NM

24P4 Federal Executive Board-Atlanta, GA

24P7 Federal Executive Board-Baltimore, MD

24Q1 Federal Executive Board-Boston, MA

24Q4 Federal Executive Board-Buffalo, NY

24Q7 Federal Executive Board-Chicago, IL

24R1 Federal Executive Board-Cincinnati, $\mathrm{OH}$

24R4 Federal Executive Board-Cleveland, $\mathrm{OH}$

24R7 Federal Executive Board-Dallas-Ft.Worth, TX

24S1 Federal Executive Board-Denver, CO

24S4 Federal Executive Board-Detroit, MI

24S7 Federal Executive Board-Honolulu, HI

24T1 Federal Executive Board-Houston, TX

24T4 Federal Executive Board-Kansas City, KS

24T7 Federal Executive Board-Los Angeles, CA

24V1 Federal Executive Board-Miami, FL

24V4 Federal Executive Board-Newark, NJ

24V7 Federal Executive Board-New Orleans, LA

24W1 Federal Executive Board-New York City, NY

24W4 Federal Executive Board-Oklahoma, City, OK

24W7 Federal Executive Board-Philadelphia, PA

24X1 Federal Executive Board-Pittsburgh, PA

24X4 Federal Executive Board-Portland, OR

24X7 Federal Executive Board-St. Louis, MO

24Y1 Federal Executive Board-San Antonio, TX

24Y4 Federal Executive Board-San Francisco, CA

$24 Y 7$ Federal Executive Board-Seattle, WA

24Z1 Federal Executive Board-Twin Cities, MN

2500 National Credit Union Administration

2600 Federal Retirement Thrift Investment Board

2700 Federal Communications Commission

2800 SOCIAL SECURITY ADMINISTRATION

2801 Office of the Commissioner

$2803 \quad$ Office of the General Counsel

$2804 \quad$ Office of the Inspector General

2805 Dep. Comm. - Fin., Assessment \& Mgmt. \& Senior Fin. Exec.

2806 Deputy Comm. - Programs, Policy, Evaluation, \& Commun.

2807

2810

Deputy Commissioner - Legislation and Congressional Affairs

2811

Deputy Commissioner - Human Resources

2812

Deputy Commissioner - Systems

2814

Deputy Commissioner - Operations

Office of the Chief Actuary 
2900 Federal Trade Commission

3100 Nuclear Regulatory Commission

3300 Smithsonian Institution

3320 Smithsonian Institution, except units admin under separate Bds of Trustees

3352 John F. Kennedy Center for the Performing Arts

3355 National Gallery of Art

3358 Woodrow Wilson International Center for Scholars

3400 U.S. International Trade Commission

3600

3601

3602

3603

3604

3605

3606

3607

3608

3610

3611

3612

3613

3615

3616

3617

3618

3619

3620

3621

3622

3623

3624

3625

3627

3628

3630

3632

3633
VETERANS AFFAIRS, Department of

Office of the Secretary

General Counsel

Office of the Deputy Secretary

Inspector General

Assistant Secretary for Management

Assistant Secretary for Policy and Planning

Assistant Secretary for Public and Intergovernmental Affairs

Assistant Secretary for Congressional and Legislative Affairs

Board of Veterans Appeals

Assistant Secretary for Human Resources and Administration

Board of Contract Appeals

Office of Small and Disadvantaged Business Utilization

Center for Minority Veterans

Center for Women Veterans

Office of Employment Discrimination Complaint Adjudication

Special Assistant for Veterans Service Organization Liaison

Chief of Staff

Under Secretary for Health / Veterans Health Administration

Director, Austin Automation Center

Deputy Assistant Secretary for Policy

Deputy Assistant Secretary for Planning and Evaluation

Immediate Office of Assistance Secretary for Policy and Planning

Deputy Assistant Secretary for Budget

Deputy Assistant Secretary for Financial Management

Immediate Office of Assistant Secretary for Management

Under Secretary for Memorial Affairs / National Cemetery System

Deputy Assistant Secretary for Diversity and Equal Employment Opportunity

Director - Office of Administration 
3634

3636

3637

3638

3640

3641

3643

3646

3644

3645

3647

3648

3649

3650

3651

3652

3655

3656

4100

4500

4567

4602

4607

4608

4609

4700

4701

4703

4704

4705

4707

4708

4712

4717

4722

4724

4728

4732

4740

4743

Deputy Assistant Secretary for Human Resources Management and Labor Relations

Immed. Office - Assist. Sec’y for Public \& Intergov. Affairs

Deputy Assistant Secretary for Intergovernmental Affairs and International

Affairs

Deputy Assistant Secretary for Public Affairs

Under Secretary for Benefits / Veterans Benefit Administration

Deputy Assist. Sec'y for Office of Resolution Management

Deputy Assist. Sec’y for Acquisition and Materiel Management

Immediate Office of Assistant Secretary for Congressional and and Legislative Affairs

Director - Asset Enterprise Management

Associate Deputy for Labor - Management Relations

Director, Congressional Affairs

Deputy Assistant Secretary for Legislative Affairs

Immed. Office - Assist. Sec’y - Human Resources \& Admin.

Assistant Secretary for Information and Technology

Immediate Office of the Assist. Sec. - Info. \& Technology

Deputy Assistant Sec. For Information \& Technology

Deputy Assistant Secretary for Security Preparedness

Deputy Assistant Secretary for Security and Law Enforcement

Merit Systems Protection Board

Equal Employment Opportunity Commission

Interagency Committee on Employment of People with Disabilities

Appalachian Regional Commission

Interstate Commission on the Potomac River Basin

The Port Authority of NY and NJ

Washington Metropolitan Area Transit Authority

\section{GENERAL SERVICES ADMINISTRATION}

Immediate Office of the Administrator

Office of General Counsel

Office of Inspector General

Office of the Chief People Officer

Office of Congressional and Intergovernmental Affairs

Office of Citizen Services and Communications

GSA Board of Contract Appeals

Office of the Chief Financial Officer

Offices of the Regional Administrators

Office of Civil Rights

Office of Small Business Utilization

Office of the Federal Acquisition Service

Public Buildings Service

Office of Childcare 
4745 Office of Governmentwide Policy

4750 Office of the Chief Information Officer

4760 Office of the Chief Acquisition Officer

4808 National Bipartisan Commission on the Future of Medicare

4817 State Justice Institute

4827 Commission on Ocean Policy

4835 Medicare Payment Advisory Commission

4836 Commission on Executive, Legislative and Judicial Salaries

4849 Office of Navajo and Hopi Indian Relocation

4856 Nuclear Waste Technical Review Board

4860 United State-China Economic and Security Review Commission

4864 U.S. Commission on International Religious Freedom

4900 NATIONAL SCIENCE FOUNDATION

4960 National Science Board

4965 Arctic Research Commission

49SA International Astronomical Union

49SB International Union of Biological Sciences

49SC International Union of Pure and Applied Chemistry

49SD International Union of Geodesy and Geophysics

49SE International Geological Union

49SF International Union of Pure and Applied Physics

49SG International Geographical Union

49SK International Union of Biochemistry \& Molecular Biology

49SM International Mathematical Union

49SN International Union of Nutritional Sciences

49SO International Commission on Optics

49SP International Union of Physiological Sciences

49SQ International Union for Quaternary Research

49SR International Union of Radio Sciences

49SS International Union of Psychological Science

49ST International Union of Theoretical and Applied Mechanics

49SU International Council of Scientific Unions

49SV International Union for Pure and Applied Biophysics

49SW International Union of Microbiological Societies

49SX International Union of Crystallography

49SY Pacific Science Association

49SZ Committee on Science and Technology for Development

5000 Securities and Exchange Commission

5094 Securities Investor Protection Corporation

5100 Federal Deposit Insurance Corporation

5400 Federal Labor Relations Authority 
5600 Central Intelligence Agency

5700 AIR FORCE, Department of the (Headquarters, USAF)

5701

Air Force Management Engineering Agency

5702

Air Force Inspection and Safety Center

5703

5704

5705

5706

5707

5708

5709

5711

570B

$570 \mathrm{D}$

570I

$570 \mathrm{~J}$

$570 \mathrm{~K}$

$570 \mathrm{M}$

$570 \mathrm{~N}$

$570 \mathrm{R}$

$570 \mathrm{U}$

$570 \mathrm{Y}$

571A

$571 \mathrm{C}$

$571 \mathrm{G}$

$571 \mathrm{~L}$

$571 \mathrm{M}$

5710

571P

571Q

571S

$571 \mathrm{~W}$

5727

5728

5729

$572 \mathrm{~A}$

572B

$572 \mathrm{C}$

572D

$572 \mathrm{E}$

$572 \mathrm{~F}$

$572 \mathrm{G}$

$572 \mathrm{H}$

Air Force Operational Test and Evaluation Center

Air Force Communications Agency

Air Force Intelligence Service

Air Force Audit Agency

Air Force Office of Special Investigations

Air Force Office of Security Police

Air Force Personnel Center

Air Force Manpower Agency

U.S. Air Force Academy

U.S. Air Forces, Europe

Air Reserve Personnel Center

Air Training Command

Air University

Headquarters, Air Force Reserve

Immediate Office, Headquarters, USAF

Pacific Air Forces

Air Force Headquarters Air Intelligence Agency

Air Force Communications Command

Air Force C2 \& Intelligence, Surveillance, \& Reconnaissance

Air Combat Command

Air Force Logistics Management Agency

Air Mobility Command

Air Force Materiel Command

Air Force Center for Quality and Management Innovation

Air Force Real Property Agency

HQ AF Flight Standards Agency

Space Command

Air Force Engineering and Services Center

Air Force Agency for Modeling and Simulation

Air Force Communication and Information Center

Air Force National Security Emergency Preparedness

Air Force Cost Center

Air Force Doctrine Center

Air Force Civilian Personnel Management Center

Air Force Personnel Operations Agency

Air Force Legal Services Center

Air Force Medical Services Center

Air Force Service Information and News Center

Air Force Combat Operations Staff 
572I

$572 \mathrm{~K}$

572L

$572 \mathrm{M}$

$572 \mathrm{~N}$

572P

$572 \mathrm{Q}$

572R

$572 \mathrm{~S}$

$572 \mathrm{~T}$

$572 \mathrm{U}$

$572 \mathrm{~V}$

$572 \mathrm{~W}$

$572 \mathrm{X}$

$572 \mathrm{Y}$

$572 Z$

5734

573C

573D

573G

573I

$573 \mathrm{~K}$

573L

$573 \mathrm{M}$

$573 \mathrm{~N}$

5730

573Q

573R

573S

573T

573V

573W

$573 Y$

$573 Z$

$574 Z$

$57 \mathrm{NG}$

57ZG

57ZS
Air National Guard Support Center

U.S. Air Force Historical Research Center

Air Force Technical Applications Center

Air Force Review Boards Office

Air Force Center for Studies and Analyses

Air Force Center for International Programs

Air Weather Service

Air Force Program Executive Office

HQ NORAD

Air Force Supply Center

Air Force Morale, Welfare and Recreation Center

Air Force Disposal Agency

Air Force District of Washington

Air Force Real Estate Agency

Air Force Pentagon Communications. Agency

HQ Air Force Medical Operations Agency

Air National Guard Units (Mobilization) (Title 5)

Air Force Elements, U.S. Central Command

Air Force Elements, U.S. Special Operations Command

Air Force Elements, Europe

Reservist, Centrally Managed

HQ U.S. European Command

Center for Air Force History

Air Force Elements, U.S. Southern Command

Air Force Elements, U.S. Atlantic Command

Air Force Elements, U.S. Pacific Command

Air Force Elements, U.S. Strategic Command

Air Force Elements, U.S. Readiness Command

Headquarters, U.S. Space Command and NORAD

Air Force Elements U.S. Transportation Command

Air Force Elements, Other than Europe

Air Force Center for Environmental Excellence

Air Force Frequency Management Center

Joint Services Survival, Evasion, Resistance and Escape Agency

Air National Guard

Air National Guard Units (Title 32)

U.S. Special Operations Command (ANG Title 32)

U.S. Special Operations Command (Air Force)

5900 NATIONAL FOUNDATION ON THE ARTS AND THE HUMANITIES

5915 Federal Council on the Arts and the Humanities

5920 National Endowment for the Arts

5940 National Endowment for the Humanities

5950 Institute of Museum Services

5963 National Council on the Arts 


\author{
5966 National Council on the Humanities \\ 6000 Railroad Retirement Board \\ 6100 Consumer Product Safety Commission \\ 6201 Office of Special Counsel \\ 6300 National Labor Relations Board \\ 6400 Tennessee Valley Authority \\ 6500 Federal Maritime Commission
}

\author{
6800 ENVIRONMENTAL PROTECTION AGENCY \\ 6801 Immediate Office of the Administrator of EPA \\ 6802 Deputy Administrator \\ 6803 Office of General Counsel \\ 6804 Office of the Inspector General \\ 6805 Assistant Administrator for Administration and Resources Management \\ 6809 Assistant Administrator for International Affairs \\ 680S Office of the Administrator of EPA \\ 6820 Assistant Administrator for Air and Radiation \\ 6825 Assistant Administrator for Enforcement and Compliance Assurance \\ 6830 Assistant Administrator for Prevention, Pesticides, and Toxic Substances \\ 6840 Assistant Administrator for Research and Development \\ 6845 Assistant Administrator for Water \\ 6850 Assistant Administrator for Solid Waste and Emergency Response \\ 6853 Office of the Chief Financial Officer \\ 6860 Commission on Risk Assessment and Risk Management \\ 68SA Associate Administrator for Office of Public Affairs \\ 68SB \\ 68SC \\ 68SD \\ 68SE \\ Associate Administrator for Congressional and Intergovernmental Relations \\ Office of Homeland Security \\ 68SF \\ 68SG \\ $68 \mathrm{SH}$ \\ 68SJ \\ $68 \mathrm{SK}$ \\ 68SL \\ Environmental Appeals Board \\ Executive Secretariat \\ Office of Executive Services \\ Office of Administrative Law Judges \\ Office of Civil Rights \\ $68 \mathrm{SM}$ \\ Office of Cooperative Environmental Management \\ Office of Small and Disadvantaged Business Utilization \\ Office of Policy, Economics and Innovation \\ Science Advisory Board
}


6900 TRANSPORTATION, Department of

6904 Office of Inspector General

690S Office of the Secretary of Transportation

6920 Federal Aviation Administration

6925 Federal Highway Administration

6930 Federal Railroad Administration

6938 Maritime Administration

6940 National Highway Traffic Safety Administration

6943 Research and Innovative Technology Administration

6947 Saint Lawrence Seaway Development Corporation

6953 Federal Motor Carrier Safety Administration

6955 Federal Transit Administration

6957 Pipeline and Hazardous Materials Safety Administration

6959 Surface Transportation Board - formerly ICC - code 3000

6991 National Railroad Passenger Corporation (AMTRAK)

7000 HOMELAND SECURITY, Department of

7001 Office of the Secretary, Department of Homeland Security

7002

7003

7004

7008

7009

7012

7013

7014

7015

7022

7032

7033

7040

7041

7050

7051

Immediate Office of the Secretary

U.S. Citizenship and Immigration Services

Office of the Inspector General

U.S. Coast Guard

U.S. Secret Service

U.S. Immigration and Customs Enforcement

Transportation Security Administration

U.S. Customs and Border Protection

Federal Law Enforcement Training Center

Federal Emergency Management Agency

Office for Information Analysis

Office for Infrastructure Protection

Under Secretary for Science and Technology

Under Secretary for Management

7100 Overseas Private Investment Corporation

7200 U.S. Agency for International Development

7300 Small Business Administration

7360 National Women's Business Council

7400 American Battle Monuments Commission 
7500 HEALTH AND HUMAN SERVICES, Department of

7501

7502

7503

7504

7505

7506

7507

7508

7509

7510

$750 S$

7511

7512

7515

7516

7520

7521

7522

7523

7524

7525

7526

7527

7528

7529

7530

7545

7555

7590

7635

7800

7881

7884

7886

7888

7889
Immediate Office of the Secretary of Health and Human Services

Office of the Deputy Secretary of Health and Human Services

Office of the General Counsel

Office of the Inspector General

Office of Assistant Secretary for Administration and Management

Office of Assistant Secretary for Planning and Evaluation

Office of Assistant Secretary for Legislation

Office of Assistant Secretary for Public Affairs

Office of Intergovernmental Affairs and Regional Directors

Office of the Assistant Secretary for Resources and Technology

Office of the Secretary of Health and Human Services

Office for Civil Rights

Office of Assistant Secretary for Public Response

Office of Public Health and Science

Departmental Appeals Board

Public Health Service

Office of the Surgeon General

Substance Abuse and Mental Health Services Administration

Centers for Disease Control and Prevention

Food and Drug Administration

Agency for Toxic Substances and Disease Registry

Health Resources and Services Administration

Indian Health Service

Agency for Healthcare Research and Quality

National Institutes of Health

Centers for Medicare \& Medicaid Services

Administration on Aging

Program Support Center

Administration for Children and Families

Christopher Columbus Fellowship Foundation

Farm Credit Administration

Bank for Cooperatives

Farm Credit Banks

Farm Credit System Financial Assistance Corporation

Farm Credit System Insurance Corporation

Federal Agricultural Mortgage Corporation (Farmer Mac)

8000 NATIONAL AERONAUTICS AND SPACE ADMINISTRATION

8001 Headquarters, NASA

8020 Ames Research Center 
8022 Dryden Flight Research Center

8025 NASA Shared Services Center

8026 Goddard Space Flight Center

8029 NASA Management Office, Jet Propulsion Laboratory

8032 Lyndon B. Johnson Space Center

8035 John F. Kennedy Space Center

8038 Langley Research Center

8041 John H. Glenn Research Center at Lewis Field

8044 George C. Marshall Space Flight Center

8047 John C. Stennis Space Center

8291 Neighborhood Reinvestment Corporation

8300 Export-Import Bank of the U.S.

$8400 \quad$ United States Soldiers' and Airmen's Home

84AF Armed Forces Retirement Home

8600 HOUSING AND URBAN DEVELOPMENT, Department of

8601 Office of the Secretary of Housing and Urban Development

8602 Deputy Secretary of Housing and Urban Development

8603 Office of General Counsel

8604 Office of Inspector General

8605 Assistant Secretary for Administration

8606 Office of Chief Financial Officer

8607 Assistant Secretary for Congressional and Intergovernmental Relations

8608 Assistant Secretary for Public Affairs

8611 Assistant Secretary for Fair Housing and Equal Opportunity

$8613 \quad$ HUD Board of Contract Appeals

$8615 \quad$ Office of Administrative Law Judges

$8617 \quad$ Office of Small and Disadvantaged Business Utilization

8620 Assistant Secretary for Community Planning and Development

8622 Assistant Deputy Secretary for Field Policy and Management

8625 Government National Mortgage Association (Ginnie Mae)

8627 Office of Departmental Equal Employment Opportunity

8630 Assistant Secretary for Housing--Federal Housing Commissioner

8635 Assistant Secretary for Public and Indian Housing

8645 Assistant Secretary for Policy Development and Research

8651 Office of Departmental Operations and Coordination

8652 Office of the Chief Information Officer

8653 Office Healthy Homes and Lead Hazard Control

8654 Office of the Chief Procurement Officer

8658 Center for Faith-based and Community Initiatives

8659 Office of Field Policy and Management

865A Office of the Field Policy and Management Region I, Boston Regional Office 
865B Office of the Field Policy and Management Region II, New York Regional Office

865C Office of the Field Policy and Management Region III, Philadelphia Regional Office

865D Office of Field Policy and Management Region IV, Atlanta Regional Office

865E Office of Field Policy and Management Region V, Chicago Regional Office

865F Office of Field Policy and Management Region VI, Fort Worth Regional Office

865G Office of Field Policy and Management Region VII, Kansas City Regional Office

865H Office of Field Policy and Management Region VIII, Denver Regional Office

865J Office of Field Policy and Management Region IX, San Francisco Regional Office

865K Office of Field Policy and Management Region X, Seattle Regional Office

8681 Federal National Mortgage Association (Fannie Mae)

8683 Federal Home Loan Mortgage Corporation (Freddie Mac)

\section{NATIONAL ARCHIVES AND RECORDS ADMINISTRATION}

8852 Information Security Oversight Office

8861 National Archives Trust Fund Board

8862 National Historical Publications and Records Commission

8865 Administrative Committee of the Federal Register

8900 ENERGY, Department of

8901 Office of the Secretary

8903 Office of the General Counsel

8904 Office of the Inspector General

8905 Assistant Secretary for Congressional and Intergovernmental Affairs

8906 Office of Hearings and Appeals

8911 Office of Civilian Radioactive Waste Management

8915 Office of Public Affairs

8917 Assistant Secretary for Environmental Management

$8921 \quad$ Assistant Secretary for Energy Efficiency and Renewable Energy

$8925 \quad$ Office of Science

8927

8928

Office of Nuclear Energy, Science and Technology

Assistant Secretary for Fossil Energy

8929

Office of Intelligence

8932

Office the of the Energy Information Administration

8936

Office of Legacy Management

8938

8955

Assistant Secretary for Policy and International Affairs

Consolidated Business Center

8974

Strategic Petroleum Reserves

8981

Casper Naval Pet \& Oil Shale Reserves

8982

8990

$891 \mathrm{C}$

Elk Hills Naval Pet \& Oil Shale Reserves

Federal Energy Regulatory Commission

$891 \mathrm{H}$

Office of Economic Impact and Diversity

$891 \mathrm{~N}$

Office of Health, Safety and Security

891S

Office of the Chief Information Officer

Office of the Departmental Representative to the Defense Nuclear Facilities 
Safety Board

892E Office of the Secretary of Energy Advisory Board Support Office

892H Office of Counterintelligence

892L Office of Electricity Delivery and Energy Reliability

893C Office of the Chief Financial Officer

893H Office of Human Capital Management

893M Office of Management

89AL

89BA

Albuquerque Operations Office (non-NNSA) (EM)

89BB

Chicago Office

Oak Ridge Office

89BC

Ames Site Office

89BD

Argonne Site Office

89BE

Berkeley Site Office

89BF

89BG

Brookhaven Site Office

89BH

Fermi Site Office

89BI

Pacific Northwest Site Office

89BJ

89BK

89BP

Princeton Site Office

89CB

$89 \mathrm{GO}$

Stanford Site Office

89ID

Thomas Jefferson Site Office

89N0

$89 \mathrm{~N} 1$

Bonneville Power Marketing Administration

Carlsbad Field Office

Golden Field Office

Idaho Operations Office

89N2

Deputy Under Secretary for Counterterrorism

Deputy Administration for Defense Programs

$89 \mathrm{N3}$

Deputy Administrator for Defense Nuclear Nonproliferation

Deputy Administrator for Naval Reactors

89N4

$89 \mathrm{~N} 5$

Office of Emergency Operations

Associate Administrator for Facilities and Operations

89N6

Associate Administrator for Management and Administration

89N7

Associate Administrator for Defense Nuclear Security

89NA

Office of Nuclear Security/National Nuclear Security Administration

89NE

$89 \mathrm{NV}$

National Energy Technology Laboratory

Nevada Operations Office (non-National Nuclear

Security Administration) (Environmental Management)

89NW

Oakland Operations Office (non-National Nuclear

Security Administration) (Environmental Management)

89OH Ohio Field Office

89PP

Portsmouth and Paducah Project Office

89RF

Rocky Flats Project Office

89RL

89RP

Richland Operations Office

89SE

89SR

Office of River Protection

89SV

Southeastern Power Marketing Administration

Savannah River Operations Office

89SW

Savannah River Site Office

Southwestern Power Marketing Administration 


$\begin{array}{ll}\text { 89WA } & \text { Western Area Power Marketing Administration } \\ \text { 89X1 } & \text { Pittsburgh Naval Reactors } \\ \text { 89X2 } & \text { Schenectady Naval Reactors } \\ \text { 89XQ } & \text { Y-12 Site Office } \\ \text { 89XR } & \text { Pantex Site Office } \\ \text { 89XS } & \text { Sandia Site Office } \\ \text { 89XT } & \text { Kansas City Site Office } \\ \text { 89XU } & \text { Los Alamos Site Office } \\ \text { 89XV } & \text { Nevada Site Office } \\ \text { 89XW } & \text { Livermore Site Office } \\ \text { 89ZA } & \text { National Nuclear Security Administration Service Center } \\ & \end{array}$

9100 EDUCATION, Department of

9101 Immediate Office of the Secretary of Education

9102 Office of the Deputy Secretary of Education

9103 Office of the General Counsel

9104 Office of Inspector General

9105 Office of Management

9106 Office of the Chief Financial Officer

9107 Office of Legislation and Congressional Affairs

9108 Office of the Under Secretary

9109 Office of Office of Communications and Outreach

9110 Office of Planning, Evaluation and Program Development

9111 Office for Civil Rights

9115 Office of the Chief Information Officer

9120 Office of Vocational and Adult Education

9121 Office of English Language Acquisition

9124 Office of Special Education and Rehabilitative Services

$9125 \quad$ National Institute on Disability and Rehabilitation Research

$9126 \quad$ Rehabilitation Services Administration

$9127 \quad$ Office of Special Education Programs

9128 Immed. Office - Assist. Sec'y for Spec. Ed. \& Rehab. Services

9129 Fund for the Improvement of Postsecondary Education

9130 Immediate Office of the Assist. Sec'y for Postsecondary Education

9131 Federal Student Aid

9132 Immediate Office of the Director of Education Sciences

$9133 \quad$ Office of Higher Education Programs

9134 Office of Postsecondary Education

9135

9136

9137

9138

9139

National Center for Education Research

National Center for Special Education Research

National Center for Educational Evaluation and Regional Assistance

National Center for Education Statistics

Institute of Education Sciences 
9140

9141

9142

9143

9144

9145

9146

9147

9150

9155

916A

916B National Assessment Governing Board

916C National Institute for Literacy

916D Federal Interagency Committee on Education

9181 Student Loan Marketing Association (Sallie Mae)

9182 College Construction Loan Insurance Association (Connie Lee)

9191 American Printing House for the Blind

9192 Gallaudet University

9193 Howard University

9194 National Technical Institute for the Deaf

9300 Federal Mediation and Conciliation Service

9502 National Capital Planning Commission

9504 Federal Mine Safety and Health Review Commission

9506 Federal Election Commission

9507 Commodity Futures Trading Commission

9508 National Transportation Safety Board

9509 National Council on Disability

9510 Harry S. Truman Scholarship Foundation

9512 Japan-U.S. Friendship Commission

9513 Marine Mammal Commission

9514 Occupational Safety and Health Review Commission

9516 Defense Nuclear Facilities Safety Board

9517 Commission on Civil Rights

9518 Committee for Purchase from People who are Blind or Severely Disabled

9520 Privacy and Civil Liberties Oversight Board

9521 Commission to Eliminate Child Abuse and Neglect Fatalities

9522 Centennial of Flight Commission

9523 Election Assistance Commission

9524 National Mediation Board

9525 National Counterintelligence Center

9526 Gulf Coast Ecosystem Restoration Council

9527 National Commission on Libraries and Information Science

9528 Office of the Federal Coordinator Alaska Natural Gas Transportation Projects

9529 World War I Centennial Commission 
9530 Advisory Council On Historic Preservation

9531 United States Holocaust Memorial Museum

9532 Architectural and Transportation Barriers Compliance Board

9535 Institute of Am. Indian and Alaska Native Culture and Arts Development

9537 Commission of Fine Arts

9540 Federal Housing Finance Agency

9541 James Madison Memorial Fellowship Foundation

9542 Office of the Inspector General of the Federal Housing Finance Agency

9543 Millennium Challenge Corporation

9545 Morris K. Udall Scholar. \& Excellence in Nat'l Enviro. Policy Foundation

9547 Delta Regional Authority

9549 Office of Government Ethics

9554 Interagency Council on the Homeless

9555 National Communications System

9558 Consumer Financial Protection Bureau

9559 Federal Reserve System, Board of Governors

9560 Barry Goldwater Scholarship and Excellence in Education Foundation

9562 Federal Financial Institutions Examination Council

9563 Financial Crisis Inquiry Commission

9565 Chemical Safety and Hazard Investigation Board

9567 Commission for the Preservation of America's Heritage Abroad

9568 Broadcasting Board of Governors

9570 Presidio Trust

9572 Delani Commission

9574 White House Commission on the National Moment of Remembrance

9577 Corporation for National and Community Service

9580 United States Institute of Peace

$9585 \quad$ Financing Corporation (FICO)

9589 United Mine Workers of America Benefit Funds

9590 Valles Caldera Trust

9591 Vietnam Education Foundation

9593 U.S. Court of Veterans Appeals

9594 Court Services and Offender Supervision Agency for the District of Columbia

959D Office of the Director - CSOSA

959P Pretrial Services Agency - CSOSA

95HL Federal Home Loan Banks

$9668 \quad$ Mississippi River Commission

96CE U.S. Army Corps of Engineers - civil program financing only

96NC Permanent International Association of Navigation Congresses

96RC Permanent International Association of Road Congresses

9700 DEFENSE, Department of (except military departments)

9736 Army/Air Force Exchange Service

9748 Defense Human Resources Activity 
9758 Defense Prisoner of War/Missing Personnel Office

$9759 \quad$ Consolidated Metropolitan Technical Personnel Center

9760 TRICARE Management Activity

$9761 \quad$ Defense Threat Reduction Agency

9762

9763

Defense Career Management and Support Agency

9765

Defense Contract Management Agency

9766

9767

9769

9770

9771

Pentagon Force Protection Agency

Department of Defense Counterintelligence Field Activity

Unified Combatant Command Headquarters

National Defense University

Armed Forces Radiobiology Research Institute

Defense Microelectronics Activity

9772

9773

9774

Pentagon Renovation Program Office

Virginia Contracting Activity

Defense Technical Information Center

$97 \mathrm{AB}$

National Geospatial-Intelligence Agency

97AD

Office of the Secretary of Defense

97AE

Defense Advanced Research Projects Agency

$97 \mathrm{AK}$

Defense Information Systems Agency

97AQ

Defense Legal Services Agency

97AR

Defense Contract Audit Agency

97AS

97AT

Defense Logistics Agency

97AU

Defense Security Cooperation Agency

97AV

Defense Technology Security Administration

97AZ

Defense Security Service

97BJ

Defense Commissary Agency

97BZ

Organization of the Joint Chiefs of Staff

97CG

Defense Finance and Accounting Service

97DL

97EX

97F1

97F2

97F5

National Security Agency/Central Security Service

Defense Intelligence Agency

Office of the Inspector General

American Forces Information Service

97F6

97GZ

97JC

Department of Defense Education Activity

Washington Headquarters Services

Office of Economic Adjustment

U.S. Court of Appeals for the Armed Forces

Missile Defense Agency

$97 \mathrm{NH}$

United States Naval Home 


\section{Appendix A Revision History}

The following codes have been added, deleted or changed in this publication:

\section{Revison 1:}

9528 Office of the Federal Coordinator Alaska Natural Gas Transportation Projects (new)

7521 Office of the Surgeon General (Name change)

7505 Office of Assistant Secretary for Administration and Management (Name change)

7510 Office of Assistant Secretary for Resources and Technology (new)

7512 Office of Assistant Secretary for Public Response (new)

8906 Office of Hearings and Appeals (Name change)

\section{Revision 2:}

9540 Federal Housing Finance Agency (FHFA) (name change)

6901 Immediate Office of the Secretary of Transportation (deleted)

6917 Deputy Secretary of Transportation (deleted)

6902 Associate Deputy Secretary/Office of Intermodalism (deleted)

6916 Office of Drug and Alcohol Policy and Compliance (deleted)

6903 Office of General Counsel (deleted)

6905 Assistant Secretary for Administration (deleted)

6906 Assistant Secretary for Budget and Programs/Chief Financial Officer (deleted)

6907 Assistant Secretary for Governmental Affairs (deleted)

6908 Assistant Secretary - Office of Public Affairs (deleted)

6909 Assistant Secretary for Transportation Policy (deleted)

6911 Office of Civil Rights (deleted)

6912 Board of Contract Appeals (deleted)

6914 Executive Secretariat (deleted)

6915 Office of Intelligence, Security and Emergency Response (deleted)

6918 Office of Small and Disadvantaged Business Utilization Business Resources Center (deleted)

6910 Office of the Chief Information Officer (deleted)

6922 Assistant Secretary for Aviation and International Affairs (deleted)

6913 Office of Commercial Space Transportation (deleted)

1416 Office of Historic Trust Accounting (DoI) (new)

1401 Office of the Secretary (DoI) (new)

1536 Antitrust Division (DoJ) (new)

1502 Civil Division (DoJ) (new)

1522 Community Oriented Policing Services (DoJ) (new)

1503 Criminal Division (DoJ) (new)

1505 Civil Rights Division (DoJ) (new)

1506 Environment and Natural Resources Division (DoJ) (new)

1507 Foreign Claims Settlement Commission (DoJ) (new)

1508 Justice Management Division (DoJ) (new)

1523 National Drug Intelligence Center (DoJ) (new)

1525 National Security Division (DoJ) (new)

1509 Office of the Assistant Attorney General (DoJ) (new) 
1510 Office of the Attorney General (DoJ) (new)

1511 Office of the Deputy Attorney General (DoJ) (new)

1527 Office of Dispute Resolution (DoJ) (new)

1537 Office of the Federal Detention Trustee (DoJ) (new)

1512 Office of Information Policy (DoJ) (new)

1529 Office of Intergovernmental and Public Liaison (DoJ) (new)

1513 Office of Legislative Affairs (DoJ) (new)

1514 Office of Legal Counsel (DoJ) (new)

1531 Office of Legal Policy (DoJ) (new)

1515 Office of the Pardon Attorney (DoJ) (new)

1538 Office of Privacy and Civil Liberties (DoJ) (new)

1516 Office of Professional Responsibility (DoJ) (new)

1517 Office of the Solicitor General (DoJ) (new)

1532 Office on Violence Against Women (DoJ) (new)

1518 Office of Public Affairs (DoJ) (new)

1533 Professional Responsibility Advisory Office (DoJ) (new)

1519 Tax Division (DoJ) (new)

1520 United States National Central Bureau (DoJ) (new)

1521 United States Parole Commission (DoJ) (new)

2413 Chief Human Capital Leadership and Merit System Accountability (OPM) (new)

2407 Division for Human Capital Leadership and Merit System Accountability (OPM) (new)

2408 Division for Strategic Human Resource Policy (OPM) (new)

2415 Federal Executive Board or Federal Executive Association (OPM) (new)

2409 Federal Investigative Service Division (OPM) (new)

2412 Federal Prevailing Rate Advisory Committee (OPM) (new)

2411 Human Resources Line of Business Office (OPM) (new)

2410 Management Services Division (OPM) (new)

2403 Office of Communications and Public Liaison (OPM) (new)

2404 Office of Congressional Relations(OPM) (new)

2405 Office of Inspector General(OPM) (new)

2406 Office of the Chief Financial Officer (OPM) (new)

2401 Office of the Director (OPM) (new)

2402 Office of the General Counsel (OPM) (new)

2414 Other Division or Office Designations (OPM) (new)

9561 Recovery Accountability and Transparency Board (deleted)

9563 Financial Crisis Inquiry Commission (new)

9558 Consumer Financial Protection Bureau (new)

8656 Office of Federal Housing Enterprise Oversight (deleted)

1435 Bureau of Ocean Energy Management (BOEM) (DoI) (name change)

1436 Bureau of Safety and Environmental Enforcement (DoI) (new)

2047 Office of Thrift Supervision (Treasury) (deleted)

2036 Bureau of the Public Debt (Treasury) (deleted)

2033 Financial Management Service (Treasury) (deleted)

2042 Bureau of the Fiscal Service (new)

1861 Postal Regulatory Commission (name change)

9520 Privacy and Civil Liberties Oversight Board (new) 
9521 Commission to Eliminate Child Abuse and Neglect Fatalities (new)

9526 Gulf Coast Ecosystem Restoration Council (new)

9529 World War I Centennial Commission (new)

9542 Office of the Inspector General of the Federal Housing Finance Agency (new)

2094 District of Columbia Public Schools (new)

0500 Government Accountability Office (name change) 